\title{
Is there shareholder expropriation in the United States? An analysis of publicly-traded subsidiaries
}

\author{
Vladimir Atanasov \\ College of William and Mary \\ Audra Boone \\ University of Kansas \\ David Haushalter \\ Pennsylvania State University
}

May 2008

JEL Classification: G32; G34

Keywords: ownership structure; expropriation; consolidation; equity carve-out

We would like to thank an anonymous referee, Maya Atanasova, Bernard Black, Gennaro Bernile, Ted Boone, Paul Fischer, James Hilliard, Clifford Holderness, Ed Ketz, Diana Knyazeva, Laurie Krigman, Tim Kruse, David Mauer, Vassil Mihov, Darius Miller, Eric Powers, Brian Schmutz, and seminar participants at the University of Arkansas, Concordia University, the University of Connecticut, the University of Delaware, McGill University, the University of North Carolina, the 2006 Association of Financial Economists Meeting, the 2006 Financial Management Association European Meeting, and the 2006 Washington Area Finance Association Meeting for helpful comments. Penelope Cray provided expert editorial assistance. Contact information: vladimir.atanasov@mason.wm.edu, alboone@ku.edu, dhaushalter@psu.edu. 


\title{
Is there shareholder expropriation in the United States? An analysis of publicly-traded subsidiaries
}

\begin{abstract}
This paper examines the relation between the performance and valuations of publicly-traded subsidiaries in the United States and the ownership stake of their parent companies. Crosssectional and time-series tests demonstrate that subsidiaries in which the parent owns a substantial minority stake exhibit negative peer-adjusted operating performance and are valued at a $23 \%$ median discount relative to peers. In contrast, majority-owned and fully divested subsidiaries show no abnormal performance or valuations. The results of our study indicate that the association between parent ownership and subsidiary performance is nonlinear and that some parents do, in fact, behave opportunistically toward their publicly traded subsidiaries.
\end{abstract}




\section{Is there shareholder expropriation in the United States? An analysis of publicly-traded subsidiaries}

\section{Introduction}

Contrary to the general view that publicly-traded firms in the United States are diffusely owned, blockholders in these firms are both frequent and substantial. Holderness (2008) finds that in a sample of U.S. firms, $96 \%$ have one or more blockholders that, on average, own an aggregate stake of 39\%. Despite the prevalence of blockholders, their effect on firm value is unresolved. On the one hand, Jensen and Meckling (1976) posit that large investors, by undertaking valuable monitoring services, can use their power to ameliorate agency problems and thereby increase firm value for all shareholders. On the other hand, Schleifer and Vishny (1997) argue that this same power enables controlling shareholders to extract private benefits at the expense of other shareholders.

Empirical evidence regarding the impact of blockholders on firm value is also mixed. Studies of firms outside the United States find that controlling shareholders frequently act opportunistically. Indeed, Johnson et al. (2000), Nenova (2002), Lemmon and Lins (2003), Dyck and Zingales (2004), Atanasov (2005), and Cheung, Rau, and Stouraitis (2006) all present evidence that controlling shareholders do extract gains — or engage in practices known as expropriation or tunneling-from non-controlling shareholders, particularly in emerging markets.

The extent and means of expropriation practiced by blockholders in U.S. firms, however, remain unclear. Studies of majority-owned companies in the United States by Holderness and Sheehan (1988, 2000) and Bates, Lemmon, and Linck (2006) find scant evidence of shareholder expropriation, a circumstance they attribute to powerful legal constraints on controlling- 
blockholder behavior. Indeed, Reese and Weisbach (2002) and Doidge, Karolyi, and Stulz (2004) argue that non-U.S. firms choose to cross-list on U.S. stock exchanges precisely to bolster their shareholder protections and curtail controlling shareholders' ability to extract private benefits.

In light of the ambiguity regarding blockholder opportunism in the United States, our study contributes to previous research in two ways. First, we examine majority and non-majority blockholdings separately. While common wisdom suggests that majority shareholders have both the greatest ability and the greatest incentive to conduct self-dealing transactions, research shows that non-majority blockholders can still wield de facto control over corporate resources (Zwiebel, 1995). Furthermore, we argue that the net gain a blockholder stands to realize from expropriation is inversely related to that blockholder's level of ownership. This, in fact, gives non-majority blockholders greater incentives to engage in wealth-redistributing activities than their majority counterparts.

Second, we examine corporate blockholders exclusively. Previous studies show that corporate blockholders are common among corporations in the United States. Barclay, Holderness, and Sheehan (2008) and Fee, Hadlock, and Thomas (2006) each find that approximately $18 \%$ and $15 \%$ of their respective samples have a non-financial corporate blockholder. Yet, only a handful of papers study the impact of corporate owners on firm value (see, for example, Allen and Phillips, 2000), and no existing work investigates the risks of shareholder expropriation posed by these corporate blockholders. Despite the lack of research on this subject, we argue that understanding corporate blockholder behavior is particularly important because intercompany transactions offer them ways to expropriate that are simply not available to other types of blockholders. Furthermore, the incentives of a corporate parent (and 
its executives) to expropriate wealth from a subsidiary can differ significantly from the incentives of individuals, financial institutions or other blockholders.

Our analysis employs a sample of 264 U.S. subsidiaries that were each separated from their parent corporation via an initial public offering, known as an equity carve-out. We follow the financial performance of these subsidiaries for the four years following the initial carve-out; divide these subsidiaries into three groups based on the fraction of shares owned by the parent firm; and identify annual changes in ownership levels. Our three ownership groups break down as follows: 1) majority-owned subsidiaries in which the parent owns a 50 to $99 \%$ stake; 2) minority-owned subsidiaries in which the parent owns a 5 to $49 \%$ stake; and 3) completelydivested subsidiaries in which the parent owns less than a 5\% stake.

In order to determine whether subsidiary performance is associated with parent ownership, we focus our empirical tests on the subsidiary's financial performance and document several key results. First, we find that subsidiary operating performance varies depending on the parent's ownership stake. Indeed, while majority-owned and completely-divested subsidiaries experience normal performance, minority-owned subsidiaries perform poorly. Beginning in the second year following the carve-out, minority-owned subsidiaries exhibit negative abnormal operating returns which deteriorate further in subsequent years. Minority-owned subsidiaries which share top executives with their parents perform especially badly. Subsidiaries that switch from the majority- to the minority-owned group also demonstrate a significant decline in operating performance.

Second, we show that the relation between subsidiary value (as measured by Tobin’s q) and parent ownership stake is nonlinear. Minority-owned subsidiaries are valued at a median discount of 23\% relative to their peers; in contrast, fully divested subsidiaries have similar 
valuations to peers, while valuations of majority-owned subsidiaries actually increase with parent ownership stake. In fact, high levels of parent ownership translate into a valuation premium. We also find evidence that among all announcements of ownership change events, a subsidiary's returns are lowest around a change in parent ownership from a majority to a minority stake.

Our study suggests that blockholder opportunism, while not necessarily common in the United States, still poses a potential risk for small shareholders. We find that the risk of expropriation is a nonlinear function of the corporate blockholder's ownership stake. Parent firms owning a large, but non-majority, stake possess both the necessary means to expropriate and greater incentives to do so than majority blockholders. Indeed, while majority blockholders may still have incentives to engage in shareholder expropriation, they generally extract greater benefits from pursuing activities that help the subsidiary. Therefore majority blockholders' incentives to engage in mutually beneficial activities, such as those described by Allen and Phillips (2000) and Fee, Hadlock, and Thomas (2006), can largely offset and even exceed the incentives to expropriate.

\section{Background and Development of Hypotheses}

\section{A. Ownership, Control, and Parent Incentives to Expropriate Subsidiaries}

Shleifer and Vishny (1997) argue that large shareholders have the incentives and ability to acquire private benefits of control. Although controlling shareholders can realize benefits without harming minority shareholders, in many cases private benefits of control are associated with a diversion of wealth from other investors, which can create tension within a corporation.

In the section below we use insights from the blockholder literature to examine the case of a parent company that controls a publicly traded subsidiary. While many of the literature's theoretical results, including the nonlinear relationship between ownership stake of the 
controlling shareholder and incentives to expropriate, apply in this case, we argue that the parentsubsidiary relationship also produces unique incentives and tools for opportunistic behavior.

\section{A.1. Ownership Stake, Control, and the Cash Flow Benefits from Expropriation}

The cash flow benefits a parent blockholder stands to realize from self-dealing transactions are inversely linked to its level of ownership in the subsidiary. For example, a parent realizes no cash flow benefits by expropriating from a wholly owned subsidiary because any gains the parent makes are negated by the equivalent loss in subsidiary value. As the parent's ownership stake decreases, however, the proportional gain from expropriating increases; overcharging a subsidiary $\$ 100$ million for a service, for example, leads to a $\$ 20$ million increase in cash flow for a parent with an $80 \%$ ownership stake. Decrease the ownership stake to $20 \%$ and the same transaction yields $\$ 80$ million extra cash flow for the corporate parent.

As the incentives to expropriate increase with a decrease in ownership stake, at the same time, the parent's control, and consequently its ability to expropriate from a subsidiary decrease. The point at which the parent loses control, however, is not obvious. While a majority stake clearly grants absolute control, prior studies demonstrate that in an otherwise widely-held corporation, an ownership block of less than $50 \%$ can still provide the shareholder with de-facto control over the corporation. Zwiebel (1995), La Porta et al. (1998), and La Porta, Lopez-deSilanes, and Shleifer (1999) argue that an ownership block of as little as 20\% can be sufficient for a parent to exercise complete control over a subsidiary. Moreover, long-term business contracts and representation on the subsidiary's board can provide the parent with additional means to control the subsidiary with less than majority ownership. 


\section{A.2. Ownership and Accounting Benefits of Expropriation}

The accounting method used when a parent reports a subsidiary’s income or assets and liabilities on its own financial statements depends on the parent's ownership stake in the subsidiary. ${ }^{1}$ A parent that controls a subsidiary with a majority stake must use the consolidation method to account for the subsidiary's performance whereas a parent that owns a substantial but non-controlling stake of a subsidiary must use the equity method. Finally, a parent with a less substantial stake accounts for the performance of the subsidiary using the fair value method.

It is important to note here that while our discussion focuses on how accounting methods affect the parent's financial statements and incentives to expropriate, the subsidiary's financial statements remain wholly unaffected by the method the parent uses to account for subsidiary performance.

Under the consolidation method, a parent firm incorporates the subsidiary’s income statement, balance sheet, and statement of cash flows into its own financial statements, and both companies are reported as a single accounting entity. Thus, any accounting benefits produced by expropriation activities are almost entirely negated in the parent's financial statements.

While 50\% ownership of voting stock acts, in most cases, as the threshold that determines use of the consolidation method for accounting, the critical ownership threshold for tax purposes sits at $80 \%$. Indeed, at ownership levels of $80 \%$ and above, the parent and subsidiary are treated as a single entity for tax purposes; losses in one company can be used to offset profits in the other and no tax liability is generated on intercompany dividend payments (see Barclay, Holderness, and Sheehan, 2008, and papers cited within).

\footnotetext{
${ }^{1}$ The rules of accounting for a subsidiary are described in Financial Accounting Standards (FAS) 115 and 94 , Accounting Principles Board (APB) 18, and Accounting Review Bulletin (ARB) 51.
} 
A significant, but non-controlling, ownership stake in a subsidiary dictates that the parent use the equity method to account for its stake. The equity method requires that the parent only recognize a proportionate share of the subsidiary's earnings, and allows the parent to exclude the subsidiary's assets and liabilities from its balance sheet, thereby enabling the parent to alter its own sales, Earnings Before Interest, Taxes, Depreciation and Amortization (EBITDA), operating cash flow, return on capital, and other accounting performance measures through dealings with the subsidiary. Transactions with terms that favor the parent will improve its reported performance while reducing the subsidiary's performance. ${ }^{2}$

If the parent holds a small ownership stake of the subsidiary, generally less than $20 \%$, it accounts for this stake using the fair-value method. This method treats the parent's stake in the subsidiary like an investment in a marketable security, and the parent must only report dividends received or gains and losses on the sale of equity investments. The fair-value method enables parent managers to improve any parent performance measure at the expense of the subsidiary because the full effect of intercompany transactions would be reported on the parent financials. Of course, with an ownership stake at this level, the parent might not have the ability to control the terms of these transactions.

Generally speaking, the incentive for parent managers to improve parent accounting performance via expropriation from a subsidiary depends, first, on the extent to which their compensation is predicated on accounting-based measures and, second, how accounting rules determined by the parent ownership stake affect intercompany transactions. While companies generally do not report the specific accounting measures they use to determine managerial

\footnotetext{
${ }^{2}$ For tax purposes, the relevant ownership threshold is $20 \%$ for minority-owned subsidiaries. At ownership levels below $20 \%$, the parent can deduct $70 \%$ of paid dividends and must pay profit tax on the remaining $30 \%$. At ownership levels above $20 \%$, the deduction is increased to $80 \%$ of paid dividends.
} 
compensation, prior research shows that many such measures play key roles in making these determinations. For example, using a proprietary data set of executive compensation policies, Murphy (1999) reports that accounting-based performance measures are widely used to determine compensation; earnings per share and return on assets, the most common of these measures, are often used in conjunction with EBITDA, sales growth, economic value added, or other accounting based performance measures. While most of the accounting performance measures listed are difficult or impossible to improve upon by transacting with a consolidated subsidiary, they are relatively easy to boost through transactions with an unconsolidated one. Parent managers thus have stronger incentives to behave opportunistically toward unconsolidated subsidiaries.

\section{A.3. Other Incentives Affecting Expropriation}

Our discussion to this point has focused on incentives that can push a parent to expropriate from their subsidiary. There are, however, other factors in play that might mitigate these incentives. If, for example, a parent intends to sell the subsidiary, it might attempt to improve, or prop, the subsidiary's performance. Furthermore, if the parent consolidates subsidiary operations, then while propping would have a negligible effect on the parent's financial statements, it could substantially improve the subsidiary's financial statements. Propping may therefore be preferable to expropriating when part of the parent managers' compensation is based on the subsidiary's accounting performance or when the parent managers own a larger equity stake in the subsidiary than they do in the parent.

Threats of lawsuits by subsidiary shareholders can also mitigate expropriation activities. While the full scope of legal standards is too complex to cover in this paper, corporate law works to limit the amount of private benefits taken by controlling shareholders. Depending on the 
circumstances of the intercompany dealings, legal standards dictate particular rules of conduct or can require judicial review. Gilson and Gordon (2003) provide an extensive overview of the legal rules that govern controlling shareholders.

\section{B. Hypotheses}

We formulate two testable hypotheses. The first focuses on whether or not parent firms expropriate wealth from their subsidiaries. The null hypothesis, in this case, is that no expropriation takes place, meaning all subsidiaries have zero peer-adjusted performance and there is no association between subsidiary performance and the parent's ownership stake. The alternative is that subsidiaries do, in fact, face expropriation risk and their performance is therefore associated with the parent's stake.

Our second hypothesis focuses on how expropriation takes place. A controlling shareholder could expropriate from minority shareholders in a variety of ways. As discussed by Johnson et al. (2000) and Atanasov, et al. (2007), a parent can transfer wealth to itself via an ongoing diversion of cash flow or assets that we call operational transactions. Operational transactions include business dealings between the parent and subsidiary that are not conducted on an arms-length basis and are intended to favor the parent.

Controlling-shareholders can also expropriate from existing or future investors through market timing, as discussed by Powers (2003), Nanda (1991), and Hand and Skantz (1999). Under the market timing form of expropriation, parent managers sell subsidiary stock to take advantage of non-public information about the subsidiary's future underperformance. In these cases, the parent liquidates or reduces its ownership in the subsidiary before the information becomes public, allowing the parent to fetch an inflated price from uninformed investors for the sold stake. 
Predictions based on the operational transactions and market-timing hypotheses are summarized in Table 1. Both hypotheses predict that minority-owned subsidiaries will underperform; however, examining the performance of the completely-divested subsidiaries enables us to distinguish between these hypotheses. The market-timing hypothesis, on the one hand, predicts that completely-divested subsidiaries will underperform more severely than minority-owned subsidiaries. On the other hand, the operational transactions hypothesis predicts normal performance for completely-divested subsidiaries, because the parents lose their ability to expropriate once they no longer own a stake in their subsidiaries.

[Insert Table 1 here]

Ideally, to test the operational transactions hypothesis, we would examine the market's reaction to the announcement of business transactions between the parent and the subsidiary, an approach similar to that used in a study of tunneling in Hong Kong by Cheung, Rau, and Stouraitis (2006). Unfortunately, the firms in our sample rarely make announcements regarding these activities. In general, disclosures of intercompany transactions between the parent and subsidiary are made, at best, only quarterly; usually transaction disclosures are made on an annual basis, the specific terms of most intercompany transactions are typically not provided. Although a systematic analysis of intercompany transactions is therefore not possible, examples of such transactions are provided in the Appendix. We are able to identify these cases primarily because the alleged parent expropriation led to lawsuits filed by aggrieved subsidiary shareholders. The information published in connection with these lawsuits provides more detail about the extent of parent-subsidiary transactions than what is usually disclosed in the subsidiary annual filings. According to the examples in the Appendix, transactions range from loans (Enron and EOG), contractual agreements to provide services (Beeba Creations and Body Drama), and 
asset sales (Motorola and Iridium, Coca Cola and CCE), to ongoing customer-supplier relationships (Coca Cola and CCE). These activities often account for a substantial part of the subsidiary’s operations.

Because we cannot rely on news or legal announcements of ongoing activities between a parent and subsidiary to inform our research, we must investigate their effects indirectly. This means analyzing the subsidiary's accounting and stock returns in four principal ways: first, we compare the operating return on assets of fully divested, unconsolidated, and consolidated subsidiaries; second, we examine the change in the subsidiary's operating return on assets (ROA) following changes in the parent's ownership stake; third, we analyze the abnormal stock returns around ownership-change events; and fourth, we compare the Tobin's q of the three types of subsidiaries.

Each of these empirical tests focuses only on subsidiaries and ignores the parents because our hypotheses offer less clear predictions about parent performance. While both market timing and cash flow diversion should result in improved parent performance, parent managers could feasibly "save up" such techniques for use only when they expect parent performance to decline. Equally, it is difficult to remove the effect of consolidated subsidiaries on parent financials and thus to compare parents that do not consolidate their subsidiaries with parents that do. With these limitations in mind, we include only two tests of parent performance: a comparison of parent and subsidiary ROA and an assessment of the correlation between parent and subsidiary cumulative abnormal stock returns around ownership change events.

\section{Data}

Equity carve-outs offer us a sample of publicly traded subsidiaries in which public parent corporations command a wide range of ownership levels. This variation in ownership is 
necessary, for our purposes, to address the effects of different ownership and accounting decisions on subsidiary performance. Parent firm ownership stakes at the subsidiary’s initial public offering (IPO) range from zero to 95\%, and, as demonstrated by Boone (2002), many parents retain a significant stake in their subsidiaries for at least four years after the carve-out. Other parents alter their stakes immediately after the IPO by buying, selling, or distributing shares of the subsidiary. Therefore, we find that subsidiaries' ownership structures vary both across ownership levels and over time.

Furthermore, both the parents and carved-out subsidiaries are public companies, which allows us to collect detailed information about their ownership structure and accounting and stock performance. Because carved-out subsidiaries were initially a division of the parent, they are often associated with a significant number of parent-subsidiary relationships, including buyer/supplier agreements, joint marketing and R\&D, and debt guarantees, to name a few. As discussed by Hoyle, Shaefer, and Doupnik (2004), such long-term relationships generate substantial intercompany asset transfers and opportunities for the parent to exert control over the subsidiary beyond its ownership stake.

An alternative approach to identifying corporate blockholders is to focus on companies that purchase a block stake in another company, as practiced by Allen and Phillips (2000). The fraction of equity purchased by corporate blockholders, however, is usually relatively small— Allen and Phillips report that corporations purchase an average stake of $20 \%$ and a median stake of $14 \%$ — and would therefore limit our ability to examine the association between variation in ownership level and expropriation risk. 


\section{A. Sample Selection}

We obtain prospective equity carve-outs for the period 1985-2000 from a list of initial public offerings compiled by the Securities Data Corporation (SDC). An initial screen excludes unit offerings, non-U.S. firms, and firms with an offering price of less than $\$ 5$. We augment this list of firms by including any additional IPOs that Mergers \& Acquisitions lists as carve-outs. Additionally, we require that the parent firm be a U.S. publicly traded company.

These two sources generate a total list of 349 potential carve-outs. We eliminate firms from the sample that are a joint venture with another firm or are constructed as a limited partnership. Finally, we drop observations in which either the parent or subsidiary does not have sufficient stock price or accounting information. Imposing these criteria reduces the final sample to 264 equity carve-outs from 232 parent firms. ${ }^{3}$ We follow subsidiaries for a four-year period, which allows time for parents to adjust their level of ownership.

\section{B. Summary Statistics}

Our sample yields an average of 16.5 carve-outs per year, with the number of carve-outs in a single year dropping to seven in 1985 and soaring to 35 in 1996. Carved-out subsidiaries are quite large, averaging $\$ 2.2$ billion in assets at the IPO and accounting for approximately $30 \%$ of the assets of the pre-IPO parent company. Roughly $40 \%$ of the parents and their subsidiaries are in the same Fama-French (1997) 48-industry portfolio, and a substantial fraction of the parents maintain ongoing involvement with the subsidiary. Indeed, approximately $58 \%$ of the subsidiaries have a top executive (Chair, President, or CEO) that is affiliated with the parent firm

\footnotetext{
${ }^{3}$ Eighteen companies conducted two carve-outs, while American Express, Atlantic Richfield, Lincoln National, Telephone \& Data Systems, each conducted three carve-outs. Thermo Electron and its various subsidiaries accounted for ten carve-outs.
} 
and 68\% have either business dealings or financial agreements with the parent (54\% have business relationships and $45 \%$ have financial agreements).

Of the 264 observations in our sample, there are 199 observations in which the parent retains a majority stake immediately after the carve-out. Initially, there are 44 observations in which the parent retains a minority stake and 21 cases in which the parent completely divests of its stake. These findings are consistent with Allen and McConnell (1998) and Schipper and Smith (1986). As shown in Figure 1, however, the parent's stake often changes in the four years following the carve-out. By the end of Year 4, 176 of the 264 subsidiaries are still publicly traded: 81 in which the parent makes a complete divestiture, and 95 in which the parent holds a partial stake. Among the 95 showing parent ownership in Year 4, 26 are minority-owned, a ratio of minority- to majority-owned subsidiaries similar to that of Years 1, 2, and 3.

\section{[Insert Figure 1 here]}

While tax considerations help explain the choice of parent ownership above 80\%, parents opt for a wide range of ownership levels. That ownership clusters around $50 \%$ is consistent with parents weighing the benefits of retaining majority control and consolidating the subsidiary, on the one hand, and relinquishing majority control and thereby avoiding the requirement to consolidate, on the other. Figure 1 demonstrates that within this ownership region parents are more likely to maintain minority ownership. In untabulated results, we find that at the end of Year 1 parent ownership falls between 40 and $60 \%$ for 70 subsidiaries from our sample. Of these 70, 45 firms are minority-owned (with an ownership stake between 40 and 49\%) and 25 firms are majority-owned (with an ownership stake between 50 and 60\%). Similarly, by the end of Year 2, the ownership of 57 subsidiaries falls within this 40 to 60\% range, with 21 majorityowned and 36 minority-owned subsidiaries. 
Finally, we inspect the financial statements of those parent firms that hold a minority share of the subsidiary. During our sample period, even though some parents hold stakes as high as $49.97 \%$, none of these parents choose to consolidate the subsidiary in their financial statements.

\section{Analysis and Results}

\section{A. Cross-Sectional Operating Performance}

We test our hypotheses primarily by comparing measures of abnormal performance for the unconsolidated subsidiaries to those of consolidated or completely-divested subsidiaries. Because concerns about consolidation accounting rules can affect the parent's choice of ownership level—and therefore the probability that expropriation will occur-we divide our sample into three ownership categories: fully divested (ownership below 5\%), unconsolidated (ownership between 5 and 50\%), and consolidated (ownership above 50\%). In addition, we also analyze the relation between performance and a continuous measure of ownership.

To determine the effect of intercompany transactions on subsidiary performance, we measure operating performance using operating return on assets, which is defined as operating cash flow (Compustat Data Item 13) divided by total assets (Compustat Data Item 6). Operating ROA provides a more direct measure of the effect of intercompany transactions on subsidiary performance than does net income or return on equity, because operating ROA is less sensitive to differences in leverage, taxes, and depreciation.

We compute the operating ROA of the parent and subsidiary for Years 0 to 4 following the carve-out and report means and medians for the three parent ownership categories in Table 2. Although in the year of the IPO and the following year, all subsidiaries outperform their parents, in subsequent years unconsolidated subsidiaries tend to underperform the parent, while 
consolidated subsidiaries exceed the parent's performance. The parent's performance also depends on whether it holds a majority or minority stake in its subsidiary. Parents with majority stakes have constant performance across time, while parents with minority stakes experience a drop in performance in Year 1 followed by steadily increasing performance in Years 2 through 4, a trend that almost mirrors the steadily decreasing performance of their subsidiaries.

[Insert Table 2 here]

\section{A.1. Peer-Adjusted Operating Performance and Ownership}

We examine subsidiary performance using peer-adjusted operating ROA. Following Lie (2001) and Barber and Lyon (1996), we peer-adjust by first matching each of our sample subsidiaries to companies in the same Fama-French (1997) 48 industry portfolio with operating ROAs closest to the those of the subsidiaries in the year of the carve-out (Year 0). ${ }^{4}$ We then compute peer-adjusted operating ROA for the years following the carve-out by subtracting the average operating ROA of these peers from the raw operating ROA of the subsidiary.

Table 3 shows the mean and median peer-adjusted operating ROA for the four years following the initial carve-out (we don’t report Year 0 results because the peer-adjusted performance is zero by construction). We sort the subsidiaries based on the level of parent ownership at the end of each year. To mitigate the influence of outliers on these statistics, we winsorize peer-adjusted operating ROA by setting the values in the bottom and top one percentiles to the values of the $1^{\text {st }}$ and $99^{\text {th }}$ percentiles, respectively.

\footnotetext{
${ }^{4}$ More specifically, we construct the benchmark portfolios using at least five matching firms. We initially identify firms in the industry with an operating ROA in Year 0 that is within $10 \%$ of the sample firms (i.e., if the sample firm's operating ROA is 5\%, we look for comparable firms with an operating ROA between $4.5 \%$ and $5.5 \%$ ). If fewer than five companies meet these criteria, we look for firms that are within one percentage point of the sample firm's operating ROA (i.e., $4 \%$ and $6 \%$ ). If fewer than five companies fall within this band, we expand the band by a percentage point. We continue to increase this band until five matching firms are identified.
} 
The results in Table 3 demonstrate that minority-owned subsidiaries underperform their peers beginning in Year 3 following the equity carve-out. The median subsidiary's operating ROA falls 4.4\% below its peers in Year 3, and drops to 4.7\% below its peers in Year 4; the mean shortfall in operating ROA is even greater. Meanwhile, consolidated or completely divested subsidiaries exhibit no significant abnormal performance during this period. Furthermore, the median abnormal operating ROA of minority-owned subsidiaries is significantly less than that of majority-owned subsidiaries in Years 3 and 4 after the carve-out.

[Insert Table 3 here]

The apparently small underperformance of unconsolidated subsidiaries (on average around 4\%) is large when expressed in economic terms. Converting the peer-adjusted operating ROA into dollar terms by multiplying it by the value of subsidiary assets yields an average underperformance of \$25.2 million (median \$7.9 million) for Years 2 through 4 following the carve-out. On average, this underperformance equals 73\% (median 23\%) of subsidiary operating income.

To further examine the decrease in performance, we decompose ROA into two ratios: sales over assets and costs over assets. Costs include cost of goods sold (COGS) and selling, general, and administrative expenses (SG\&A). We then track changes in these ratios over time. In untabulated tests, we find that divested firms exhibit a decrease in both sales and costs, which over time produces a consistent ROA. The peer-adjusted underperformance of the unconsolidated firms stems from an increase in costs without an accompanying increase in sales.

We test for the effects of attrition bias by splitting our sample into two groups: firms that have non-missing peer-adjusted performance for all four years after the IPO (survivors) and firms that do not (dropouts). The survivors and dropouts have similar mean and median 
operating performance across ownership groups and time, which makes the results in Table 3 largely robust to survivorship issues.

\section{A.2. Regressions on Abnormal Operating Performance}

In Table 4 we report results from regressions of peer-adjusted operating ROA for each of the four years following the carve-out. These regressions include two dummy variables, the first, ownership49, equal to one when a subsidiary is minority-owned, and the second, ownership50, equal to one when a subsidiary is majority-owned. The comparison category consists of subsidiaries that are completely divested (the parent's ownership stake is less than $5 \%$ ). ${ }^{5}$ The remaining variables in the regression control for subsidiary size (defined as book value of total assets) and whether the parent and subsidiary are in the same industry (defined using Fama and French's 48 industry categories).

Panel A shows that the coefficient on the ownership49 dummy is -7\% in Year 3 and $-9 \%$ in Year 4. Similar to the results in Table 3, the abnormal performance of unconsolidated subsidiaries worsens each year. The coefficient on the ownership50 variable despite being statistically insignificant, is significantly greater than the coefficient on the ownership49 variable in Years 3 and 4 . The other variables in the regressions are generally also statistically insignificant, with the exception of the firm's total assets, which is positively associated with subsidiary peer-adjusted operating ROA.

In Panel B we extend our regression specification to control for executive overlap between the parent and the subsidiary, executive overlap describing cases where at least one of

\footnotetext{
${ }^{5}$ As discussed in Section II.A, the rules for accounting for the subsidiary performance change once the parent's ownership stake drops below the $20 \%$ level. Only a handful of firms in our sample fall into the category of parent ownership between 5 and 20\%. Because predictions for our analysis are similar for firms that fall into this category as for other firms in which the parent owns a minority stake, we include these observations with the ownership49 group.
} 
the subsidiary's top three executives (Chairman of the Board, CEO, or President) also serves as executive or director of the parent. Although the incentives for an overlapping executive to improve parent performance are not entirely clear, they are likely to be greater than the incentives driving an executive with no ties to the parent. The executive overlap dummy variable is set to one if there is overlap and is zero otherwise. We include this variable both in interaction with the ownership49 and ownership50 dummies, which detects whether executive overlap has a different effect on majority versus minority subsidiaries, and on its own.

\section{[Insert Table 4 here]}

Ultimately, the coefficient on the executive overlap dummy is insignificant, which indicates that executive overlap alone does not produce abnormal performance. The interaction between the executive overlap variable and ownership49 is negative in Year 3, and significantly less than the interactions we find between the executive overlap and ownership50 variables in Years 3 and 4. Based on these results, we conclude that much of the negative peer-adjusted performance of minority-owned subsidiaries in Years 3 and 4 is produced by subsidiaries whose top executives overlap with the parent firm.

In addition to these tests, we run two untabulated regressions: the first controls for the size of the subsidiary relative to the parent and the second controls for whether the subsidiary discloses intercompany transactions with the parent. In both cases, we find that these additional control variables are not significant. The results for the other variables are similar to those reported in Table 4.

\section{A.3. Operating Performance and Continuous Levels of Ownership}

In order to extend our analysis of ownership structure and operating performance, we examine this relation on a continuous basis. Conducting this analysis requires that we no longer 
aggregate the publicly traded subsidiaries into three ownership categories (i.e., majority-owned, minority-owned, fully divested), but instead use the actual fraction of subsidiary shares owned by the parent. In untabulated analysis we re-estimate the regressions from Table 4, using parent ownership, as well as its squared term, to identify nonlinearities in the association between ownership and performance. Our regressions find that the coefficients on ownership are negative and significant, while the coefficients on ownership squared are positive and significant, which suggests that the relation between ownership and performance is indeed nonlinear and U-shaped.

We further investigate this nonlinear relation by measuring the association between locally smoothed peer-adjusted operating ROA and parent ownership. We follow a methodology suggested by Cleveland (1979) and implemented using the lowess procedure in Stata 10 (StataCorp, 2007). First, we estimate ordinary least squares (OLS) regressions using the subsidiary's peer-adjusted operating ROA as the dependent variable and the fraction of shares owned by the parent as the independent variable. Each regression uses the $30 \%$ of sample observations closest to a particular level of ownership. Then, based on the coefficients from these regressions, we compute the predicted operating ROA in this vicinity of ownership.

Figure 2 shows the predicted level of performance from this analysis. Consistent with the results from our earlier analysis, the graph is U-shaped with the worst performance associated with parent minority ownership, particularly ownership around 25\%. For firms with ownership around this level, the peer-adjusted operating ROA is estimated at $-5 \%$. Peer-adjusted operating ROA improves for ownership less than $25 \%$ but remains negative up to the point of zero ownership by the parent. The best performing subsidiaries are those in which the parents' ownership stake exceeds $80 \%$.

[Insert Figure 2 here] 


\section{B. Changes in Operating Performance around Changes in Ownership}

To further investigate the association between ownership and subsidiary performance, we use a time series approach to study a subset of subsidiaries in which the parents' ownership stake shifts between ownership groups. Our tests monitor changes in the subsidiary's performance based on three types of ownership-altering events: the move from majority ownership to minority ownership (25 firms), minority ownership to complete divestiture (34 firms), and majority ownership to complete divestiture (72 firms). These tests compare the subsidiary's peer-adjusted operating ROA in the years after the ownership change to its peer-adjusted operating ROA before the change.

If expropriation is related to ownership levels, a decrease in the parent's ownership from a majority to a minority stake will be accompanied by a subsequent decline in subsidiary performance. Predictions for this analysis vary based on how the parental expropriation takes place. The operational transactions hypothesis predicts that the decrease in performance will be greatest when parent ownership changes from a majority to a minority stake, whereas the market timing hypothesis predicts that the decrease in performance will be greatest when parent ownership drops from a majority stake to a complete divestiture. The move from minority stake to complete divestiture is also expected to yield a decrease in performance.

The results from this analysis are shown in Table 5. Ultimately, subsidiaries whose parent reduces ownership from a majority to a minority stake, yet continues to retain some ownership through the end of Year 4, exhibit, on average, a 9\% reduction in operating ROA. This decrease in performance scales back to $6 \%$ when we include companies that are completely divested by the end of Year 4, denoted as Transitional Divests. Although some evidence suggests a decrease in performance following a change from minority ownership to complete 
divestiture, the magnitude of this underperformance is substantially less than that of the majority to minority group. There is no evidence of abnormal performance following changes from majority ownership to complete divestiture.

[Insert Table 5 here]

\section{Stock Return Performance}

Finally, in our study, we use two approaches to examine the association between the parent's ownership stake and the valuation of the subsidiary. First, we examine the market's reaction to changes in the parent's ownership stake, and second, we measure the association between the parent's ownership stake and the subsidiary's Tobin's q.

\section{C.1. Market reactions to an announcement of a change in the parent's ownership stake}

Using Lexis-Nexis news searches, we identify 147 announcements of changes in parents’ ownership stakes across ownership categories. Of these announcements, 68 mark a change in the parent's stake from majority to complete divestiture, 19 a change from majority to minority, 28 a change from minority to complete divestiture, two a change from minority to majority, and 30 a parents' reacquisition of the subsidiary. Parents use several different methods to change their stake, the most common being spin-offs to shareholders, exchange offers, secondary offerings, rights offerings, and acquisitions by a third party of all of a subsidiary's shares including the parent's stake.

Initially, we partition changes in ownership into two groups: the change from a majority to a minority stake falls into one group and all other changes fall into another. According to the operational transactions hypothesis, a change in a parent's ownership level from a majority to a minority stake will increase the parent's incentives to expropriate. The other ownership 
changes-majority to divestiture, minority to divestiture, minority to majority, and reacquisition - are expected to reduce or have no effect on these incentives. Based on this argument, a change in ownership from a majority to a minority stake will result in a negative market reaction, whereas all other ownership changes will be non-negative, assuming that these alterations are not anticipated prior to the announcement. The market-timing hypothesis, on the other hand, predicts that announcement returns will be negative for any reduction in the parent's stake and poorest when the parent divests its entire ownership stake.

Announcement cumulative abnormal returns (CARs) are shown in Panel A of Table 6. The returns for the Majority-to-Minority group are $-1.07 \%$ from day -1 to day +1 and $-8.57 \%$ from day +2 to day +30 . These values are, however, statistically insignificant, probably owing to the small number of observations in this group. In untabulated results for the Majority-toMinority group, we examine the direction of the returns and find that $68 \%$ of the Majority-toMinority group has negative returns from day -1 to day +1 and $74 \%$ has negative returns from day +2 to day +30 , the latter being significant at the $10 \%$ level. Average abnormal announcement returns from day -1 to day +1 for the All Other Changes Group equal 10.25\% and statistically exceed the returns for the Majority-to-Minority group at the $5 \%$ level. The returns for each of the subcategories that comprise the All Other Changes Group are positive.

\section{[Insert Table 6 here]}

A caveat to the results for these subcategories and the All Other Changes group as a whole is that these transactions often involve premiums paid to subsidiary shareholders when the change occurs via acquisition or reacquisition by the parent, while many of the Majority-toMinority ownership changes are executed via equity offerings, which in general are viewed negatively by the market. 
In Panel B of Table 6 we further examine the returns by estimating regressions using the CARs from day -1 to +1 as the dependent variable. The explanatory variables in these regressions include a dummy for a Majority-to-Minority change, a dummy for a seasoned equity offering, the parent announcement CAR for the same window, and an interaction type between Majority-to-Minority and parent CAR. The results show that returns around a change in ownership from a majority to a minority stake are significantly less than returns for other types of events, a trend that holds even after controlling for seasoned equity offerings.

These results also comment on the association between the subsidiary's and the parent's returns at the time of a change in ownership. The coefficient on the parent CAR is positive, which is consistent with the fact that the parent has a significant equity stake in the subsidiary. The results indicate that, around the announcement of a change in ownership, the parent's value increase by $0.27 \%$ for every $1 \%$ change in the subsidiary's value. In contrast, the coefficient on the interactive term of the parent CAR and the Majority-to-Minority dummy is negative, although it is marginally insignificant with a p-value of 0.11 . The coefficient on this term therefore implies that, around the announcement of change in ownership from a majority to a minority stake, the value of the parent increases by $0.39 \%$ for every $1 \%$ decrease in the value of the subsidiary. These results are consistent with expected parent opportunism following a Majority-to-Minority ownership change.

\section{C.2. Tobin's q and the Parent's Ownership Stake}

To elaborate on the association between ownership and company valuation, we examine the subsidiary's peer-adjusted Tobin's q. If subsidiaries risk expropriation and investors recognize this risk, then the valuation of a subsidiary should depend on the size of the parent's ownership stake. We compute the subsidiary's peer-adjusted Tobin's q as (book value of assets 
- book value of equity + market value of equity) / book value of assets, and then subtract from the result the average Tobin's q of the subsidiary peers.

Table 7 shows mean and median peer-adjusted Tobin's q for each of the years following the carve-out. The sample is again divided into three groups: fully divested subsidiaries, subsidiaries in which the parent owns a minority stake, and subsidiaries in which the parent owns a majority stake. The peer-adjusted q is, in general, insignificantly different from zero for fully divested subsidiaries and subsidiaries in which the parent owns a majority stake. Conversely, the peer-adjusted q is negative for subsidiaries in which the parent owns a minority stake; specifically, the mean peer-adjusted q is negative in Years 1 and 4 and less than the majorityowned subsidiaries in Years 1 and 3, while the median is negative and less than that of majorityowned subsidiaries in all four years. When we convert the median numbers across all years into a percentage discount by dividing them by the median peer Tobin's q, we estimate that minorityowned subsidiaries are valued at a $23 \%$ median discount relative to peers. We replicate the yearly regression analysis from Table 4 using the peer-adjusted Tobin's q as the dependent variable and find similar results.

[Insert Table 7 here]

\section{C.3. Tobin's q and Continuous Levels of Ownership}

As the final step in our study, we examine, this time on a continuous basis, the association between Tobin's q and the parent's ownership stake using the same approach employed in the analysis of operating ROA in Figure 2. This analysis is presented in Figure 3. The association between ownership and $\mathrm{q}$ is shaped like a smirk and almost mirrors the shape of Figure 2. The peer-adjusted Tobin's q again bottoms out around 25\% parent ownership. This 
ratio increases slightly with ownership below the $25 \%$ level and becomes positive when ownership exceeds $80 \%$.

\section{[Insert Figure 3 here]}

\section{Alternative Explanations for the Results}

What else might account for a subsidiary's decline in performance around a parent's decision to decrease their ownership stake? One alternative explanation is that the subsidiary's flagging performance reflects a simultaneous loss of business from the parent when it divests some of its stake. Several of our results, however, are not consistent with this explanation. First, based on this explanation we would expect the greatest decline in performance to occur when a parent divests its entire stake. Instead, we find zero abnormal performance for completely divested stakes. Second, the "loss of business" explanation cannot account for cases where performance declines despite continued affiliation between the subsidiary's officers and the parent corporation. Finally, we find that a lower ROA primarily results from increased costs rather than decreased sales, as might be expected if a loss of business were at the core of decreased performance.

Another possible explanation for the underperformance of unconsolidated subsidiaries is that parents have stronger incentives to monitor a majority-owned subsidiary than they do one in which they hold only a minority stake. This argument predicts that as parent ownership decreases, subsidiary performance will also decrease, not because of expropriation but because the parent expends less effort monitoring the subsidiary. Given the steady performance of fully divested subsidiaries, however, this monitoring argument assumes that once a parent fully divests its ownership, another blockholder will move in and adopt the monitoring role. Finally, the 
reduced monitoring argument fails to explain why the worst performance is concentrated in minority-owned subsidiaries that are managed by parent executives.

\section{Conclusion}

Our paper studies potential agency problems that can arise from blockholder opportunism by examining the performance of subsidiaries following equity carve-outs. Our results indicate that the association between a parent's ownership stake and a subsidiary's performance is nonlinear. Subsidiaries in which the parent retains a minority-stake (between 5 and 50\%) exhibit poorer operating performance and worse valuations than otherwise comparable peers. In contrast, there is no abnormal performance or valuation among subsidiaries in which a parent retains a majority stake or divests of its stake completely. Additional tests that examine levels of ownership on a continuous basis demonstrate that the relative operating performance and valuation of subsidiaries is worst at levels of parent ownership around 25\%.

The results of our study provide compelling evidence to suggest that non-controlling shareholders in the United States can and sometimes do face the risk of expropriation from their controlling corporate counterparts. Within our sample, the risk of expropriation proves greatest when a corporate blockholder holds a relatively small economic stake in its subsidiary. Moreover, we find that expropriation is more likely to take place via operational transactions between the parent and its subsidiary than via equity transactions based on market timing. Our analysis highlights the importance of acknowledging changes in incentives across three main levels of ownership_-majority, minority, and complete divestiture-changes that can easily be missed when focusing exclusively on averages across all levels of ownership. 


\section{Appendix. Selected Case Studies of Parent Expropriation of Subsidiaries}

This section examines the types of arrangements that exist between parents and their publicly traded subsidiaries. Rarely are there public announcements of transactions between a parent and its subsidiary at the time of the transaction. Transactions that are disclosed in financial filings are often vague and only provided on an annual basis. Stakeholder lawsuits (usually filed by the shareholders or creditors of the minority firm) often offer the most detailed descriptions of the dealings between a parent and a subsidiary. Therefore, we take information from the press coverage of lawsuits, supplemented with details from financial filings, to show the types of arrangements that can lead to minority shareholder expropriation.

\section{Coca-Cola Co. and Coca-Cola Enterprises}

Since selling off 51\% of its ownership in Coca-Cola Enterprises (CCE) through an equity carve-out in 1986, Coca-Cola Co. (KO) has retained a large, but minority stake in CCE. In fact, Coke has an agreement with CCE that if its ownership stake exceeds $49 \%$ because of share repurchases or other activities on the part of CCE; CCE is required to purchase its shares from Coke until its stake is back to the $49 \%$ level or below.

KO has also maintained extensive business dealings with CCE. KO accounts for the vast majority of CCE's revenues and has long-standing product contracts that restrict the ability of CCE to negotiate prices for the tangible and non-tangible assets that Coca-Cola sells to its subsidiary. Moreover, four Coca-Cola executives served on CCE's board.

KO has been accused of a wide range of transgressions in its dealings with CCE. A few of these include selling syrup to CCE at higher prices than what could be obtained in an armslength transaction, selling bottling plants and non-tangible franchise rights assets to CCE at greatly inflated prices, and pressuring CCE to reduce soft drink prices to increase the volume of 
KO's syrup sales. Additionally, in several cases CCE has issued equity to pay Coca-Cola for the assets it has obtained from Coca-Cola. Coca-Cola has recognized additional income from the proceeds of these equity issues, because of the difference in offering price and book value. These transactions account for a large portion of CCE’s business. For example, in 1997 CCE had almost two thirds of its assets as franchise rights purchased from Coca-Cola.

Consistent with concerns of expropriation, CCE’s average annual peer-adjusted operating return on assets is roughly $-4 \%$ during the four years following the carve-out. ${ }^{6}$

\section{Motorola and Iridium}

Motorola owned roughly $18 \%$ of Iridium after spinning it off. Although Motorola was not required to fully consolidate Iridium's operations, there were strong ties between the two companies. The Chairman of Iridium was previously the executive vice president of Motorola. According to creditors, Motorola had approval rights over all of Iridium’s security filings.

Transactions between the companies were also extensive. Motorola was Iridium’s primary supplier. In Iridium’s 1998 10-k alone, Motorola is mentioned 515 times. In total, Iridium paid Motorola almost $\$ 5$ billion to help it build and maintain a satellite network.

In less than three years after going public, Iridium filed for bankruptcy. Creditors contend that the satellite system they were left with was worth only a fraction of the payments made to Motorola. They argue that the purpose of the arrangement was to fund the development of projects that Motorola could sell elsewhere, while passing most of the risks of the project onto

\footnotetext{
${ }^{6}$ Sources: Meyer and Owsen (1997), Meyer, Owsen, and Brozovsky (1998), Coca-Cola Enterprises, 13-G filing, 2002 and other company financial statements.
} 
outside investors (Iridium's shareholders.) ${ }^{7}$

\section{Beeba's Creations and Body Drama}

Beeba’s Creations retained a 51\% stake in Body Drama after carving it out in an IPO in 1991. Because it retained a majority stake of Body Drama, Beeba’s was required to fully consolidate the performance of Body Drama in its financial statements. Therefore, intercompany transactions affected Body Drama’s financial statements but not Beeba’s.

Contractual agreements between Body Drama and Beeba’s required Body Drama to rely on Beeba’s for management, information services, payroll processing, warehousing, and other services. Beeba's is accused of often setting the prices that it would receive from Body Drama for these services. In others words, Beeba’s was able to name its own price. Between 1991 and 1993, Body Drama’s selling, general and administrative expenses increased by 163\% although revenues only increased by $17 \%$.

In 1994 Beeba’s repurchased the remaining 49\% of Body Drama at a price that was roughly a third of its IPO price. ${ }^{8}$

\section{Enron and Enron Global Power and Pipelines}

Enron held a 58\% stake in Enron Pipelines following Enron Pipelines’ IPO in 1994. As a result of this ownership stake, subsequent intercompany transactions were fully consolidated in Enron’s filings but not in Enron Pipeline’s. In the years following the offering, four out of seven Enron Pipeline’s board members were affiliated with Enron.

\footnotetext{
${ }^{7}$ Sources: Iridium's 1998 10k and proxy statement, "Motorola may find itself on the hook for debt of railed venture iridium,” Wall Street Journal, September 27, 2006, Section C, page 1. “Iridium LLC,” case 9-200-039, Harvard Business School.

8 “Body Drama Saga includes tinge of financial intrigue,” Los Angeles Times, August 17, 1994, Section D, page 3.
} 
Transactions between Enron and Enron Pipeline include loans. The terms of the loans depended on direction. For example, in financial filings in 1997, Enron Pipeline reported that it was indebted to Enron for an aggregate amount of \$59.1 million from contractual obligations, the construction of projects, and the acquisition of partial interest in assets. Although terms are not disclosed for the entire amount of this indebtedness, Enron Pipeline does state that the interest rate on $\$ 6.3$ million of this debt ranges from 9\% to 12\%. The same filing notes that Enron is also indebted to Enron Pipelines for $\$ 7.25$ million, but that this debt was an interest-free advance.

Intercompany transactions also include Enron Pipeline buying partial interest in Enron’s assets, the scale of these transactions were sometimes substantial. For example, Enron's sale of a 48\% interest in its power plant in the Dominican Republic to Enron Pipeline accounted for roughly 14\% of Enron Pipeline’s total assets.

Finally Enron also provided services through contractual arrangement for Enron Pipelines. These services include administrative and commercial support, operations and maintenance, technical support, and fuel and management services. In 1996, total payments from Enron Pipelines to Enron for these services totaled \$66.7 million, or almost 20\% of Enron Pipeline’s Total Assets. (Reporting makes it difficult to determine their total revenues or expenses). ${ }^{9}$ In November, 1997, Enron reacquired Enron Pipelines in a stock for stock transaction.

\footnotetext{
${ }^{9}$ Sources: Enron Global Power and Pipelines LLC, Def 14A, May 14 1997, 10k March 19, 1997, 8k, June 18, 1996. “Enron’s child may play hide-n-seek: Spin-off's Independent Directors could push for big bump,” Mergers and Acquisitions Report (Security Data Publishing), May 26, 1997.
} 


\section{References}

Accounting Principles Board (APB). APB Opinion No. 18: The Equity Method of Accounting for Investments in Common Stock (1971).

Allen, J. and J. McConnell. “Equity Carve-outs and Managerial Discretion.” Journal of Finance, 53 (1998), 163-186.

Allen, J. and G. Phillips. “Corporate Equity Ownership, Strategic Alliances, and Product Market Relationships.” Journal of Finance, 55 (2000), 2791-2815.

American Institute of Certified Public Accountants, Accounting Research Bulletin (ARB) No. 51: Consolidated Finance Statements. (1959).

Atanasov, V. “How Much Value Can Blockholders Tunnel? Evidence from the Bulgarian Mass Privatization Auctions.” Journal of Financial Economics, 76 (2005), 191-234.

Atanasov, V.; B. Black; C. Ciccotello; and S. Gyoshev. "How Does Law Affect Finance? An Examination of Financial Tunneling in an Emerging Market.” ECGI Working Paper No. 123, (2007). 
Barclay, M. and C. Holderness. "Private Benefits from Control of Public Corporations.” Journal of Financial Economics, 25 (1989), 371-395.

Barclay, M.; C. Holderness; and D. Sheehan. "Dividends and Corporate Shareholders.” Review of Financial Studies, forthcoming (2008).

Barber, B. and J. Lyon. "Detecting Abnormal Operating Performance: The Empirical Power and Specification of Test-Statistics.” Journal of Financial Economics, 41 (1996), 359-400.

Bates, T.; M. Lemmon; and J. Linck, "Shareholder Wealth Effects and Bid Negotiation in Freeze-out Deals: Are Minority Shareholders Left Out in the Cold?” Journal of Financial Economics, 81 (2006), 681-708.

Boone, A. “The Interaction of Ownership, Governance, and Product markets: Evidence from Equity Carve-outs.” Working Paper, University of Kansas (2002).

Cheung, Y.; R. Rau; and A. Stouraitis. “Tunneling, Propping and Expropriation Evidence from Connected Party Transactions in Hong Kong.” Journal of Financial Economics, 82 (2006), 343386. 
Cleveland, W. "Robust Locally Weighted Regression and Smoothing Scatterplots.” Journal of the American Statistical Association, 74 (1979), 829-836.

Doidge, C.; A. Karolyi; and R. Stulz. "Why Are Foreign Firms Listed in the U.S. Worth More?” Journal of Financial Economics, 71 (2004), 205-238.

Dyck, A. and L. Zingales. “Private Benefits of Control: An International Comparison.” Journal of Finance, 59 (2004), 537-600.

Fama, E. and K. French. “Industry Costs of Equity.” Journal of Financial Economics, 43 (1997), 153-194.

Fee, E.; C. Hadlock; and S. Thomas. “Ownership and the Governance of Product Market Relationships.” Journal of Finance, 61 (2006), 1217-1251.

Financial Accounting Standards Board. Statement of Financial Accounting Standards No. 94: Consolidation of All Majority-Owned Subsidiaries: An Amendment of ARB No. 51 with Related Amendment of APB Opinion No. 18 and ARB No. 43. Stamford, CT (1987).

Financial Accounting Standards Board. Statement of Financial Accounting Standards No. 115: Accounting for Certain Investments in Debt and Equity Securities, Stamford, CT (1993). 
Gilson, R. and J. Gordon. “Controlling Controlling Shareholders.” University of Pennsylvania Law Review, 152 (2003), 785-843.

Hand, J. and T. Skantz. “The Market-timing Characteristics of Equity Carve-outs.” Working Paper, University of North Carolina (1999).

Holderness, C. “The Myth of Diffuse Ownership in the United States.” Review of Financial Studies, forthcoming (2008).

Holderness, C. and D. Sheehan. “The Role of Majority Shareholders in Publicly Held Corporations: An Exploratory Analysis.” Journal of Financial Economics, 20 (1988), 317-346.

Holderness, C. and D. Sheehan. “Constraints on Large Shareholders.” In Concentrated Corporate Ownership, R. Morck, ed. University of Chicago Press, Chicago (2000).

Hoyle, J. B.; T. Shaefer; and T. Doupnik. Advanced Accounting, $7^{\text {th }}$ Edition, McGraw Hill/Irwin (2004).

Jensen, M. and W. Meckling. Theory of the Firm: Managerial Behavior, Agency Costs, and Ownership Structure.” Journal of Financial Economics, 3 (1976), 305-360. 
Johnson, S.; R. La Porta; F. Lopez-de-Silanes; and A. Shleifer. “Tunneling.” American

Economic Review, 90 (2000), 22-27.

La Porta, R.; F. Lopez-de-Silanes; A. Shleifer; and R. Vishny. “Law and Finance.” Journal of Political Economy, 106 (1998), 1113-1155.

La Porta, R.; F. Lopez-de-Silanes; and A. Shleifer. "Corporate Ownership around the World.” Journal of Finance, 54 (1999), 471-517.

Lemmon, M. and K. Lins. “Ownership Structure, Corporate Governance, and Firm Value:

Evidence from the East Asian Financial Crisis.” The Journal of Finance, 58 (2003), 1445-1468.

Lie, E. “Detecting Abnormal Operating Performance: Revisited.” Financial Management, 30 (2001), 77-91.

Meyer, A. and D. Owsen. “Consolidated Financial Statements: What Constitutes Control and Should Coke Consolidate its Affiliates.” Analyst Report, $2^{\text {nd }}$ Opinion Research (1997).

Meyer, A; D. Owsen; and J. Brozovsky. "What is KO worth? An Unconventional and Critical Analysis of the Quality of Coca-Cola’s Earnings.” Analyst Report, $2^{\text {nd }}$ Opinion Research (1998). 
Morck, R.; A. Shleifer; and R. Vishny. “Management Ownership and Market Valuation: An Empirical Analysis.” Journal of Financial Economics, 20 (1988), 293-315.

Murphy, K. “Executive Compensation.” in O. Ashenfelter and D. Card, eds. Handbook of Labor Economics, Vol. 3, North Holland (1999).

Nanda, V. “On the Good News in Equity Carve-outs.” Journal of Finance, 46 (1991), 17171737.

Nenova, T. “The Value of Corporate Votes and Control Benefits: A Cross-Country Analysis.” Journal of Financial Economics, 68 (2002), 325-352.

Powers, E. “Deciphering the Motives for Equity Carve-outs.” Journal of Financial Research, 26 (2003), 31-50.

Reese, W. and M. Weisbach. "Protection of Minority Shareholder Interests, Cross-listings in the United States, and Subsequent Equity Offerings.” Journal of Financial Economics, 66 (2002), 65-104.

Schipper, K. and A. Smith. “A Comparison of Equity Carve-outs and Seasoned Equity Offerings: Share Price Effects of Corporate Restructuring.” Journal of Financial Economics, 15 
(1986), 153-186.

Shleifer, A. and R. Vishny. “Large Shareholders and Corporate Control.” Journal of Political Economy, 94 (1986), 461-488.

Shleifer, A. and R. Vishny. “A Survey of Corporate Governance.” Journal of Finance, 52 (1997), 737-783.

StataCorp. Stata Statistical Software: Release 10, College Station, TX (2007).

Vijh, A. “Long-term Returns from Equity Carve-outs.” Journal of Financial Economics, 51 (1999), 273-308.

Zwiebel, J. "Block Investment and Partial Benefits of Corporate Control." Review of Economic Studies, 62 (1995), 161-185. 


\section{Table 1. Empirical Predictions of the Operational Transactions and Market Timing Hypotheses vs. the Null Hypothesis of No Expropriation by Parent Companies}

This table summarizes the empirical predictions of the operational transactions and market timing hypotheses tested in this paper with regard the subsidiaries' abnormal performance and parent firm ownership. The operational transactions hypothesis predicts that the parents will have an incentive to retain a minority stake in the subsidiary to maximize the impact of wealth transfers on the parent firms' financials. The worst performance would occur in the minority stake sample. The market timing hypothesis predicts that parent firms will own fewer shares when they anticipate that their subsidiaries' performance will decline. The worst performance would occur in the fully divested sample.

$\begin{array}{ccc}\text { No Expropriation } & \text { Operational } & \text { Market Timing } \\ & \text { Transactions } & \text { Hypothesis } \\ & \text { Hypothesis } & \end{array}$

Cross-sectional comparison of performance

$\begin{array}{llll}\text { Fully Divested } & \text { Zero } & \text { Zero } & \text { Large negative }\end{array}$

$\begin{array}{lll}\text { Parent owns a minority stake } \quad \text { Zero } & \text { Large negative } & \text { Small negative }\end{array}$

Parent owns a majority stake Zero Z Z Z Small negative/zero Zero/positive

Performance changes after changes in ownership

Parent ownership drops from

majority to zero

Zero Zero/small positive Large negative

Parent ownership drops from

majority to minority

Zero

Large negative

Small negative

Parent ownership drops from minority to zero

Zero

Small Positive

Small negative 


\section{Table 2. Difference in Accounting Performance (Operating ROA) of Parents versus Subsidiaries by Ownership Level on a Year-by-Year Basis}

For Years 1 to 4 following the carve-out, the sample of subsidiaries that remain publicly traded is separated into three groups based on the fraction of shares owned by the parent at the end of year: Fully Divested, Ownership below 50\%, and Ownership above 50\%. Fully Divested includes all carve-outs in which the parent retains less than 5\% ownership stake. Ownership below 50\% includes all minority-owned carve-outs in which the parent keeps ownership below $50 \%$, but above $5 \%$, while Ownership above $50 \%$ is in which the parent retains a majority stake in the subsidiary. We measure operating performance as operating ROA, which equals the ratio of Operating Cash Flow (Compustat Data Item 13) divided by Total Assets (Compustat Data Item 6). We winsorize both parent and sub ROA by setting the values in the bottom and top one percentiles to the values of the 1st and 99th percentiles, respectively. P-values for the t-test that the means the rank test that the medians of parent and sub ROA are equal are reported in the third column of each ownership category. Below the p-values we report the number of observations that are used to compute each mean and median. ${ }^{* *}, * *, *$ indicate that differences are significant at $1 \%, 5 \%$, and $10 \%$ levels, respectively.

\begin{tabular}{|c|c|c|c|c|c|c|c|c|c|c|c|}
\hline \multirow[b]{2}{*}{$\begin{array}{l}\text { Year Out } \\
\text { from Initial } \\
\text { Carve-out }\end{array}$} & \multirow[b]{2}{*}{$\begin{array}{c}\text { Mean } \\
\text { (median) } \\
\text { Sub ROA }\end{array}$} & \multicolumn{2}{|c|}{ Fully Divested } & \multicolumn{3}{|c|}{ Ownership below 50\% } & \multicolumn{3}{|c|}{ Ownership above 50\% } & \multicolumn{2}{|c|}{$\begin{array}{c}\text { P-value for difference } \\
\text { between parent and sub ROA } \\
\text { for ownership below 50\% } \\
\text { different from above 50\% }\end{array}$} \\
\hline & & $\begin{array}{l}\text { Mean } \\
\text { (median) } \\
\text { Parent } \\
\text { ROA }\end{array}$ & $\begin{array}{l}\text { P-value of } \\
\text { difference } \\
\text { in means } \\
\text { (medians) }\end{array}$ & $\begin{array}{c}\text { Mean } \\
\text { (median) } \\
\text { Sub ROA }\end{array}$ & $\begin{array}{l}\text { Mean } \\
\text { (median) } \\
\text { Parent } \\
\text { ROA }\end{array}$ & $\begin{array}{l}\text { P-value of } \\
\text { difference } \\
\text { in means } \\
\text { (medians) }\end{array}$ & $\begin{array}{c}\text { Mean } \\
\text { (median) } \\
\text { Sub ROA }\end{array}$ & $\begin{array}{l}\text { Mean } \\
\text { (median) } \\
\text { Parent } \\
\text { ROA }\end{array}$ & $\begin{array}{l}\text { P-value of } \\
\text { difference } \\
\text { in means } \\
\text { (medians) }\end{array}$ & Mean & Median \\
\hline 0 & $\begin{array}{r}0.172 \\
(0.17) \\
12 \\
\end{array}$ & $\begin{array}{c}0.111 \\
(0.10)\end{array}$ & $\begin{array}{c}0.12 \\
(0.10)^{*}\end{array}$ & $\begin{array}{c}0.170 \\
(0.16) \\
33 \\
\end{array}$ & $\begin{array}{c}0.095 \\
(0.09)\end{array}$ & $\begin{array}{c}0.00 * * * \\
(0.00)^{* * *}\end{array}$ & $\begin{array}{r}0.121 \\
(0.12) \\
176 \\
\end{array}$ & $\begin{array}{c}0.082 \\
(0.10)\end{array}$ & $\begin{array}{l}0.00 * * * \\
(0.00)^{* * *}\end{array}$ & 0.35 & 0.18 \\
\hline 1 & $\begin{array}{r}0.170 \\
(0.14) \\
32 \\
\end{array}$ & $\begin{array}{c}0.070 \\
(0.10)\end{array}$ & $\begin{array}{r}0.00^{* * *} \\
(0.01)^{* * *}\end{array}$ & $\begin{array}{c}0.104 \\
(0.13) \\
41\end{array}$ & $\begin{array}{c}0.067 \\
(0.07)\end{array}$ & $\begin{array}{l}0.17 \\
(0.04)^{* *}\end{array}$ & $\begin{array}{r}0.105 \\
(0.11) \\
130 \\
\end{array}$ & $\begin{array}{c}0.076 \\
(0.10)\end{array}$ & $\begin{array}{l}0.04^{* *} \\
(0.01)^{* * *}\end{array}$ & 0.75 & 0.30 \\
\hline 2 & $\begin{array}{c}0.140 \\
(0.14) \\
58 \\
\end{array}$ & $\begin{array}{c}0.089 \\
(0.11)\end{array}$ & $\begin{array}{c}0.02 * * \\
(0.03)^{* *}\end{array}$ & $\begin{array}{c}0.079 \\
(0.12) \\
23 \\
\end{array}$ & $\begin{array}{c}0.094 \\
(0.08)\end{array}$ & $\begin{array}{c}0.71 \\
(0.90)\end{array}$ & $\begin{array}{r}0.115 \\
(0.10) \\
90 \\
\end{array}$ & $\begin{array}{c}0.082 \\
(0.09)\end{array}$ & $\begin{array}{l}0.02 * * \\
(0.01)^{* * *}\end{array}$ & 0.20 & 0.28 \\
\hline 3 & $\begin{array}{c}0.135 \\
(0.12) \\
56 \\
\end{array}$ & $\begin{array}{c}0.089 \\
(0.12)\end{array}$ & $\begin{array}{l}0.02 * * \\
(0.11)\end{array}$ & $\begin{array}{c}0.050 * \\
(0.09) \\
23 \\
\end{array}$ & $\begin{array}{c}0.103 \\
(0.10)\end{array}$ & $\begin{array}{c}0.13 \\
(0.06)^{*}\end{array}$ & $\begin{array}{c}0.116 \\
(0.13) \\
72 \\
\end{array}$ & $\begin{array}{c}0.084 \\
(0.09)\end{array}$ & $\begin{array}{l}0.14 \\
(0.01)^{* * *}\end{array}$ & $0.04^{* *}$ & $0.00 * * *$ \\
\hline 4 & $\begin{array}{c}0.124 \\
(0.11) \\
56\end{array}$ & $\begin{array}{c}0.108 \\
(0.12)\end{array}$ & $\begin{array}{c}0.40 \\
(0.96)\end{array}$ & $\begin{array}{c}0.046 \\
(0.09) \\
19\end{array}$ & $\begin{array}{c}0.129 \\
(0.12)\end{array}$ & $\begin{array}{l}0.18 \\
(0.04)^{* *}\end{array}$ & $\begin{array}{c}0.127 \\
(0.11) \\
57\end{array}$ & $\begin{array}{c}0.097 \\
(0.09)\end{array}$ & $\begin{array}{l}0.07 * \\
(0.07)^{*}\end{array}$ & $0.02 * *$ & $0.01 * * *$ \\
\hline
\end{tabular}




\section{Table 3. Peer-Adjusted Accounting Performance of Subsidiaries by Ownership Level on a Year-by-Year Basis}

For Years 1 to 4 following the carve-out, the sample of subsidiaries that remain publicly traded is separated into three groups based on the fraction of shares owned by the parent at the end of year: Fully Divested, Ownership below 50\%, and Ownership above 50\%. Fully Divested includes all carve-outs in which the parent retains less than 5\% ownership stake. Ownership below 50\% includes all carve-outs in which the parent keeps ownership below $50 \%$, while Ownership above 50\% is when the parent retains a majority stake in the subsidiary. We measure operating performance as operating ROA, which equals the ratio of Operating Cash Flow (Compustat Data Item 13) divided by Total Assets (Compustat Data Item 6). Operating ROA is peer-adjusted using firms in the same FamaFrench 48 industry portfolio and the closest operating ROA in Year 0. We winsorize peer-adjusted operating ROA by setting the values in the bottom and top one percentiles to the values of the 1st and 99th percentiles, respectively. P-values for the t-test that the means equal zero and the rank test that the medians equal zero are in parentheses. Below the p-values we report the number of observations that are used to compute each mean and median. ***, **** indicate significance at 1\%, 5\%, and 10\% levels, respectively.

\begin{tabular}{|c|c|c|c|c|c|c|c|c|}
\hline & \multicolumn{2}{|c|}{ Fully Divested } & \multicolumn{2}{|c|}{ Ownership below 50\% } & \multicolumn{2}{|c|}{ Ownership above 50\% } & \multicolumn{2}{|c|}{$\begin{array}{c}\text { P-value for oper. ROA } \\
\text { below } 50 \% \text { different } \\
\text { from oper. ROA above } \\
50 \%\end{array}$} \\
\hline $\begin{array}{l}\text { Year Out } \\
\text { from Initial } \\
\text { Carve-out }\end{array}$ & $\begin{array}{l}\text { Mean } \\
\text { Subsidiary } \\
\text { ROA }\end{array}$ & $\begin{array}{l}\text { Median } \\
\text { Subsidiary } \\
\text { ROA }\end{array}$ & $\begin{array}{l}\text { Mean } \\
\text { Subsidiary } \\
\text { ROA }\end{array}$ & $\begin{array}{l}\text { Median } \\
\text { Subsidiary } \\
\text { ROA }\end{array}$ & $\begin{array}{l}\text { Mean } \\
\text { Subsidiary } \\
\text { ROA }\end{array}$ & $\begin{array}{l}\text { Median } \\
\text { Subsidiary } \\
\text { ROA }\end{array}$ & $\begin{array}{c}\text { Mean } \\
\text { Subsidiary } \\
\text { ROA }\end{array}$ & $\begin{array}{c}\text { Median } \\
\text { Subsidiary } \\
\text { ROA }\end{array}$ \\
\hline 1 & $\begin{array}{c}0.013 \\
(0.24)\end{array}$ & $\begin{array}{c}0.004 \\
(0.38)\end{array}$ & $\begin{array}{l}-0.020 \\
(0.25)\end{array}$ & $\begin{array}{l}-0.001 \\
(0.92)\end{array}$ & $\begin{array}{l}-0.012 \\
(0.25)\end{array}$ & $\begin{array}{r}0.002 \\
(0.67)\end{array}$ & 0.73 & 0.75 \\
\hline & 42 & & 44 & & 143 & & & \\
\hline 2 & $\begin{array}{c}0.012 \\
(0.29)\end{array}$ & $\begin{array}{c}0.005 \\
(0.18)\end{array}$ & $\begin{array}{l}-0.015 \\
(0.43)\end{array}$ & $\begin{array}{l}-0.017 \\
(0.53)\end{array}$ & $\begin{array}{c}0.006 \\
(0.61)\end{array}$ & $\begin{array}{l}-0.002 \\
(0.58)\end{array}$ & 0.39 & 0.25 \\
\hline & 71 & & 27 & & 102 & & & \\
\hline 3 & $\begin{array}{l}-0.015 \\
(0.65)\end{array}$ & $\begin{array}{c}0.008 \\
(0.30)\end{array}$ & $\begin{array}{l}-0.082^{* * *} \\
(0.03)\end{array}$ & $\begin{array}{l}-0.045^{* *} \\
(0.02)\end{array}$ & $\begin{array}{l}-0.021 \\
(0.50)\end{array}$ & $\begin{array}{l}-0.000 \\
(0.77)\end{array}$ & 0.30 & $0.02 * *$ \\
\hline & 73 & & 24 & & 81 & & & \\
\hline 4 & $\begin{array}{l}-0.014 \\
(0.48)\end{array}$ & $\begin{array}{l}-0.004 \\
(0.95)\end{array}$ & $\begin{array}{l}-0.147 * * \\
(0.05)\end{array}$ & $\begin{array}{l}-0.047 * * \\
(0.03)\end{array}$ & $\begin{array}{l}-0.005 \\
(0.72)\end{array}$ & $\begin{array}{l}-0.005 \\
(0.78)\end{array}$ & $0.01 * * *$ & $0.05^{* *}$ \\
\hline & 75 & & 21 & & 63 & & & \\
\hline
\end{tabular}




\section{Table 4. Cross-Sectional Regressions of Subsidiary Peer-Adjusted Operating ROA}

The dependent variables are the subsidiary's adjusted operating ROA in Year 1, Year 2, Year 3, and Year 4, respectively. We define operating ROA as the ratio of Operating Cash Flow (Compustat Data Item 13) divided by Total Assets (Compustat Data Item 6). Operating ROAs are peer-adjusted by matching each subsidiary with firms in the same Fama-French 48 industry portfolio and similar operating ROA in the IPO year (Year 0). Peer-adjusted operating ROA is winsorized by setting the values in the bottom and top one percentiles to the values of the 1st and 99th percentiles. Ownership49 is a dummy equal to one if the parent retains between $5 \%$ and $50 \%$ ownership in the respective year. Ownership50 is a dummy equal to one if the parent retains more than $50 \%$ ownership in the respective year. The comparison category is parents with less than a $5 \%$ stake. Size equals the log of subsidiary assets. Same Industry is a dummy variable equal to one if the parent and subsidiary are the in the same FamaFrench 48 industry portfolio. The measure for Executive Overlap used in Panel B regressions is defined as a dummy equal to one if at least one of the subsidiary's Chairman of the Board, CEO, or President one year after the carve-out is also an executive or director in the parent company. P-values are in parentheses. ${ }^{* * *},{ }^{* *}, *$ indicate significance at $1 \%, 5 \%$, and $10 \%$ levels, respectively.

Panel A. Parent Ownership Stake and Subsidiary ROA

\begin{tabular}{lcccc}
\hline & $\begin{array}{c}\text { Subsidiary } \\
\text { Operating ROA1 }\end{array}$ & $\begin{array}{c}\text { Subsidiary } \\
\text { Operating ROA2 }\end{array}$ & $\begin{array}{c}\text { Subsidiary } \\
\text { Operating ROA3 }\end{array}$ & $\begin{array}{c}\text { Subsidiary } \\
\text { Operating ROA4 }\end{array}$ \\
\hline Ownership49 & -0.018 & -0.030 & $-0.073^{* *}$ & $-0.094^{* * *}$ \\
& $(0.47)$ & $(0.27)$ & $(0.03)$ & $(0.01)$ \\
Ownership50 & -0.011 & -0.003 & 0.004 & 0.002 \\
F-test p-value that & $(0.57)$ & $(0.88)$ & $(0.85)$ & $(0.70)$ \\
Ownership49 is different & & & & \\
from Ownership50 & 0.74 & 0.29 & $0.02^{* *}$ & $0.00^{* * *}$ \\
Control Variables & & & & \\
Size & & & $0.014^{* * *}$ & $0.017^{* *}$ \\
& $0.019 * * *$ & $0.012^{* * *}$ & $(0.01)$ & $(0.02)$ \\
Same Industry & $(0.00)$ & $(0.01)$ & -0.020 & -0.007 \\
& -0.007 & -0.018 & $(0.34)$ & $(0.75)$ \\
Constant & $(0.63)$ & $(0.28)$ & $-0.067 * *$ & $-0.100^{* * *}$ \\
\hline Number of Observations & $-0.097^{* * *}$ & $-0.048^{*}$ & $(0.05)$ & $(0.01)$ \\
Adjusted R & $(0.01)$ & $(0.08)$ & 179 & 161 \\
F-test & 230 & 200 & 0.06 & 0.10 \\
\hline
\end{tabular}


Table 4. (Cont.) Cross-Sectional Regressions of Subsidiary Peer-Adjusted Operating ROA

Panel B. Parent Ownership Stake, Executive Overlap, and Subsidiary ROA

\begin{tabular}{|c|c|c|c|c|}
\hline & $\begin{array}{c}\text { Subsidiary } \\
\text { Operating ROA1 }\end{array}$ & $\begin{array}{c}\text { Subsidiary } \\
\text { Operating ROA2 }\end{array}$ & $\begin{array}{c}\text { Subsidiary } \\
\text { Operating ROA3 }\end{array}$ & $\begin{array}{c}\text { Subsidiary } \\
\text { Operating ROA4 }\end{array}$ \\
\hline \multirow{2}{*}{ Ownership49 } & -0.022 & $-0.066^{*}$ & 0.007 & -0.054 \\
\hline & $(0.47)$ & $(0.08)$ & $(0.87)$ & $(0.22)$ \\
\hline \multirow{2}{*}{ Ownership50 } & -0.035 & -0.007 & -0.009 & -0.019 \\
\hline & $(0.19)$ & $(0.80)$ & $(0.83)$ & $(0.66)$ \\
\hline \multirow{2}{*}{ Executive Overlap } & 0.006 & 0.008 & 0.022 & 0.004 \\
\hline & $(0.88)$ & $(0.79)$ & $(0.49)$ & $(0.89)$ \\
\hline \multirow{2}{*}{$\begin{array}{l}\text { Executive Overlap* } \\
\text { Ownership49 }\end{array}$} & 0.007 & 0.064 & $-0.152 * *$ & -0.092 \\
\hline & $(0.89)$ & $(0.23)$ & $(0.02)$ & $(0.17)$ \\
\hline \multirow{2}{*}{$\begin{array}{l}\text { Executive Overlap* } \\
\text { Ownership50 }\end{array}$} & 0.029 & 0.003 & 0.007 & 0.033 \\
\hline & $(0.52)$ & $(0.94)$ & $(0.88)$ & $(0.53)$ \\
\hline $\begin{array}{l}\text { F-test p-value that Exec. } \\
\text { Overlap*Ownership49 is } \\
\text { different from Exec. } \\
\text { Overlap*Ownership50 }\end{array}$ & 0.57 & 0.24 & $0.02 * *$ & $0.09 *$ \\
\hline \multicolumn{5}{|l|}{ Control Variables } \\
\hline \multirow{2}{*}{ Size } & $0.019 * * *$ & $0.012 * * *$ & $0.014^{* * *}$ & $0.017 * * *$ \\
\hline & $(0.00)$ & $(0.01)$ & $(0.01)$ & $(0.01)$ \\
\hline \multirow[b]{2}{*}{ Same Industry } & -0.0091 & -0.020 & -0.027 & -0.010 \\
\hline & $(0.54)$ & $(0.25)$ & $(0.20)$ & $(0.64)$ \\
\hline \multirow[b]{2}{*}{ Constant } & $-0.099 * * *$ & $-0.051^{*}$ & $-0.074 * *$ & $-0.102 * * *$ \\
\hline & $(0.01)$ & $(0.09)$ & $(0.04)$ & $(0.01)$ \\
\hline Number of Observations & 229 & 200 & 179 & 161 \\
\hline Adjusted $\mathrm{R}^{2}$ & 0.09 & 0.03 & 0.08 & 0.10 \\
\hline F-test & 0.00 & 0.06 & 0.00 & 0.00 \\
\hline
\end{tabular}




\section{Table 5. Changes in Subsidiary Peer-Adjusted Operating ROA Performance following Changes in Ownership and Accounting Method}

The table shows changes in subsidiary's operating ROA relative to a change in the parent's ownership stake that alters the parent's method to account for subsidiary performance. The first ownership altering event shown in the table is for 25 parents that during the four years following the equity carve-out reduce ownership from a majority to a minority stake, and therefore stop fully accounting for subsidiary performance. Fifteen of these parents retain their minority holding to the end of Year 4 (denoted as "Retain Minority Holding"). The remaining ten parents drop ownership from majority to minority first and eventually divest all ownership (denoted by "Transitional Divest"). The second ownership altering event shown is a reduction of a minority holding to zero. Of the 34 parents, 24 start with a minority ownership in the subsidiary in the year of the carve-out and divest their ownership within four years (denoted by “Divest Minority Holding”). The other ten firms are the same "Transitional Divest” firms analyzed in the previous ownership altering event, because the drop from a majority to minority holding is followed by a drop from a minority holding to zero ownership in the subsidiary. The final ownership altering event shown is a reduction from a majority holding to zero. Of the 72 firms that experience such ownership change, 62 parents held a majority ownership in the subsidiaries immediately following the carve-out and completely divest this ownership without dropping to a minority ownership first (these are denoted by "Divest Majority Holding”). The remaining ten firms are the "Transitional Divest” firms analyzed in the previous two ownership change cases. The Change in subsidiary operating ROA measures the difference in peeradjusted operating ROA before the ownership change to after the ownership change. We winsorize peer-adjusted operating ROA by setting the values in the bottom and top one percentiles to the values of the 1st and 99th percentiles. The Change in subsidiary operating ROA is estimated by running an OLS regression with firm fixed effects and a dummy equal to 1 for the period after the ownership change. P-values for the hypotheses that the coefficient of this dummy equals zero are in parentheses. ***, **,* indicate significance at $1 \%, 5 \%$, and $10 \%$ levels, respectively.

\begin{tabular}{|c|c|c|}
\hline Ownership Altering Event & Firm Type & $\begin{array}{c}\text { Change in Subsidiary } \\
\text { Operating ROA }\end{array}$ \\
\hline \multirow{3}{*}{$\begin{array}{l}\text { Ownership reduction from majority ( }>50 \%) \text { to } \\
\text { minority holding }(<50 \%)\end{array}$} & $\begin{array}{l}\text { All firms } \\
\text { (firms }=25)\end{array}$ & $\begin{array}{l}-0.061 * * \\
(0.04)\end{array}$ \\
\hline & $\begin{array}{l}\text { Retain Minority Holding } \\
\text { (firms = 15) }\end{array}$ & $\begin{array}{l}-0.090^{* *} \\
(0.02)\end{array}$ \\
\hline & $\begin{array}{l}\text { Transitional Divest } \\
\text { (firms }=10 \text { ) }\end{array}$ & $\begin{array}{r}0.003 \\
(0.92)\end{array}$ \\
\hline \multirow{3}{*}{$\begin{array}{l}\text { Ownership reduction from minority holding } \\
(<50 \%) \text { to zero }(0 \%)\end{array}$} & $\begin{array}{l}\text { All firms } \\
(\text { firms }=34)\end{array}$ & $\begin{array}{l}-0.021^{*} \\
(0.09)\end{array}$ \\
\hline & $\begin{array}{l}\text { Divest Minority Holding } \\
\text { (firms =24) }\end{array}$ & $\begin{array}{l}-0.022 \\
(0.14)\end{array}$ \\
\hline & $\begin{array}{l}\text { Transitional Divest } \\
\text { (firms = 10) }\end{array}$ & $\begin{array}{l}-0.016 \\
(0.29)\end{array}$ \\
\hline \multirow{3}{*}{$\begin{array}{l}\text { Ownership reduction from majority holding } \\
(>50 \%) \text { to zero }(0 \%)\end{array}$} & $\begin{array}{l}\text { All firms } \\
\text { (firms }=72 \text { ) }\end{array}$ & $\begin{array}{r}0.007 \\
(0.51)\end{array}$ \\
\hline & $\begin{array}{l}\text { Divest Majority Holding } \\
\text { (firms =62) }\end{array}$ & $\begin{array}{r}0.012 \\
(0.31)\end{array}$ \\
\hline & $\begin{array}{l}\text { Transitional Divest } \\
\text { (firms =10) }\end{array}$ & $\begin{array}{l}-0.035 \\
(0.22)\end{array}$ \\
\hline
\end{tabular}




\section{Table 6. Subsidiary Returns around Announcement of Changes in Parent Ownership Stake}

Panel A reports market adjusted returns for subsidiaries around announcements of changes in the parent's ownership stake in the subsidiary. The All Other Changes group includes all Majority to Divest, Minority to Divest, Minority to Majority, and Reacquire events. The CARs of the Minority to Majority ownership change group are not reported separately because there are only two such events. ${ }^{\mathrm{a}}$ Indicates the difference between majority to minority and other changes in ownership is significant at the 5\% level. Panel B reports the results from set of regressions which have the subsidiary's CARs for the $(-1,1)$ window as the dependent variable. The independent variables include a dummy for Majority to Minority Change, a dummy SEO equal to 1 for Seasoned Equity Offering, parent company CAR for the $(-1,1)$ window, and an interaction term between the Majority to Minority dummy and parent CAR. ***, **, * indicate significance at $1 \%$, $5 \%$, and $10 \%$ levels, respectively.

Panel A. Announcement Returns around Changes in Parent Ownership Stake

\begin{tabular}{|c|c|c|c|c|c|c|c|c|c|c|}
\hline \multirow[b]{2}{*}{$\begin{array}{l}\text { Announcement } \\
\text { Window }\end{array}$} & \multicolumn{2}{|c|}{$\begin{array}{c}\text { Majority to Minority } \\
\text { (19 events) }\end{array}$} & \multicolumn{2}{|c|}{$\begin{array}{c}\text { Majority to Divest } \\
\text { (68 events) }\end{array}$} & \multicolumn{2}{|c|}{$\begin{array}{c}\text { Minority to Divest } \\
\text { (28 events) }\end{array}$} & \multicolumn{2}{|c|}{$\begin{array}{c}\text { Reacquire } \\
\text { (30 events) }\end{array}$} & \multicolumn{2}{|c|}{$\begin{array}{l}\text { All Other Changes } \\
\text { (128 events) }\end{array}$} \\
\hline & $\begin{array}{c}\text { Subsidiary } \\
\text { CAR }\end{array}$ & P-value & $\begin{array}{l}\text { Subsidiary } \\
\text { CAR }\end{array}$ & P-value & $\begin{array}{l}\text { Subsidiary } \\
\text { CAR } \\
\end{array}$ & P-value & $\begin{array}{c}\text { Subsidiary } \\
\text { CAR } \\
\end{array}$ & P-value & $\begin{array}{l}\text { Subsidiary } \\
\text { CAR } \\
\end{array}$ & P-value \\
\hline-30 to -2 & $2.20 \%$ & 0.62 & $0.12 \%$ & 0.49 & $11.50 \% * * *$ & 0.01 & $4.93 \% *$ & 0.06 & $3.19 \% * *$ & 0.02 \\
\hline-1 to +1 & $-1.07 \%$ & $0.52^{\mathrm{a}}$ & $8.27 \% * * *$ & 0.01 & $10.11 \% *$ & 0.06 & $16.23 \% * * *$ & 0.01 & $10.25 \% * * *$ & 0.01 \\
\hline+2 to +30 & $-8.57 \%$ & $0.14^{\mathrm{a}}$ & $0.02 \%$ & 0.73 & $8.26 \% * * *$ & 0.01 & $1.98 \%$ & 0.30 & $1.88 \%$ & 0.23 \\
\hline
\end{tabular}

Panel B. Regressions on Subsidiary Cumulative Abnormal Returns $(-1,1)$

\begin{tabular}{|c|c|c|c|c|c|c|}
\hline & \multicolumn{2}{|c|}{ Model 1} & \multicolumn{2}{|c|}{ Model 2} & \multicolumn{2}{|c|}{ Model 3} \\
\hline & Coefficient & P-Value & Coefficient & P-Value & Coefficient & P-Value \\
\hline Majority-to-Minority & $-0.113^{* * *}$ & 0.01 & $-0.085^{*}$ & 0.07 & -0.036 & 0.45 \\
\hline SEO & & & $-0.111^{* * *}$ & 0.01 & $-0.110 * * *$ & 0.01 \\
\hline Parent CAR & & & & & $0.269 * * *$ & 0.01 \\
\hline Majority-to-Minority * Parent CAR & & & & & -0.663 & 0.11 \\
\hline Number of Observations & 147 & & 147 & & 137 & \\
\hline Adjusted $\mathrm{R}^{2}$ & 0.03 & & 0.07 & & 0.09 & \\
\hline
\end{tabular}




\section{Table 7. Subsidiary Peer-Adjusted Tobin's q and Parent Ownership Stake}

For Years 1 to 4 following the carve-out, the sample of subsidiaries that remain publicly traded is separated into three groups based on the fraction of shares owned by the parent at the end of year: Fully Divested, Ownership below 50\%, and Ownership above 50\%. Fully Divested includes all carve-outs in which the parent retains less than $5 \%$ ownership stake. Ownership below 50\% includes all carve-outs in which the parent keeps ownership below $50 \%$, while Ownership above 50\% is when the parent retains a majority stake in the subsidiary. We measure Tobin's $\mathrm{q}$ as (Market Value of Equity + Book Value of Assets - Book Value of Equity)/Book Value of Assets. This ratio is then peer-adjusted using firms in the same Fama-French 48 industry portfolio and the closest operating ROA in Year 0 . We winsorize peer-adjusted q by setting the values in the bottom and top one percentiles to the values of the 1st and 99th percentiles, respectively. P-values for the t-test that the means equal zero and the rank test that the medians equal zero are in parentheses. Below the p-values we report the number of observations that are used to compute each mean and median. ${ }^{* * *}, * *, *$ indicate significance at $1 \%, 5 \%$, and $10 \%$ levels, respectively.

\begin{tabular}{|c|c|c|c|c|c|c|c|c|}
\hline & \multicolumn{2}{|c|}{ Parent Fully Divested } & \multicolumn{2}{|c|}{$\begin{array}{c}\text { Parent Ownership below } \\
50 \%\end{array}$} & \multicolumn{2}{|c|}{$\begin{array}{l}\text { Parent Ownership } \\
\quad \text { above } 50 \%\end{array}$} & \multicolumn{2}{|c|}{$\begin{array}{l}\text { P-value for Tobin's q } \\
\text { below } 50 \% \text { different } \\
\text { from Tobin’s q above } \\
50 \% \\
\end{array}$} \\
\hline & $\begin{array}{l}\text { Subsidiary } \\
\text { Mean q }\end{array}$ & $\begin{array}{l}\text { Subsidiary } \\
\text { Median q }\end{array}$ & $\begin{array}{l}\text { Subsidiary } \\
\text { Mean q }\end{array}$ & $\begin{array}{l}\text { Subsidiary } \\
\text { Median q }\end{array}$ & $\begin{array}{l}\text { Subsidiary } \\
\text { Mean q }\end{array}$ & $\begin{array}{l}\text { Subsidiary } \\
\text { Median q }\end{array}$ & $\begin{array}{l}\text { Subsidiary } \\
\text { Mean q }\end{array}$ & $\begin{array}{l}\text { Subsidiary } \\
\text { Median q }\end{array}$ \\
\hline \multirow[t]{2}{*}{1} & $\begin{array}{l}-0.160 \\
(0.33)\end{array}$ & $\begin{array}{l}-0.036 \\
(0.14)\end{array}$ & $\begin{array}{l}-0.441^{* * *} \\
(0.01)\end{array}$ & $\begin{array}{l}-0.386^{* * *} \\
(0.01)\end{array}$ & $\begin{array}{l}0.431^{* * *} \\
(0.01)\end{array}$ & $\begin{array}{l}-0.033 \\
(0.40)\end{array}$ & $0.01^{* * *}$ & $0.01 * * *$ \\
\hline & 43 & & 43 & & 144 & & & \\
\hline \multirow[t]{2}{*}{2} & $\begin{array}{l}-0.255 \\
(0.46)\end{array}$ & $\begin{array}{l}-0.037 \\
(0.26)\end{array}$ & $\begin{array}{l}-1.336 \\
(0.15)\end{array}$ & $\begin{array}{l}-0.399 * * * \\
(0.01)\end{array}$ & $\begin{array}{l}-0.492 \\
(0.29)\end{array}$ & $\begin{array}{r}0.140 \\
(0.67)\end{array}$ & 0.40 & $0.04 * *$ \\
\hline & 70 & & 27 & & 99 & & & \\
\hline \multirow[t]{2}{*}{3} & $\begin{array}{l}-0.288 \\
(0.43)\end{array}$ & $\begin{array}{l}-0.066 \\
(0.12)\end{array}$ & $\begin{array}{l}-0.706 \\
(0.17)\end{array}$ & $\begin{array}{l}-0.384 * * \\
(0.04)\end{array}$ & $\begin{array}{r}0.093 \\
(0.62)\end{array}$ & $\begin{array}{l}-0.078 \\
(0.89)\end{array}$ & $0.07 *$ & $0.02 * *$ \\
\hline & 72 & & 24 & & 78 & & & \\
\hline \multirow[t]{2}{*}{4} & $\begin{array}{l}-0.236 \\
(0.51)\end{array}$ & $\begin{array}{l}-0.084 \\
(0.40)\end{array}$ & $\begin{array}{l}-0.956^{*} \\
(0.10)\end{array}$ & $\begin{array}{l}-0.353^{* *} \\
(0.04)\end{array}$ & $\begin{array}{l}-0.22 \\
(0.60)\end{array}$ & $\begin{array}{l}-0.111 \\
(0.60)\end{array}$ & 0.37 & $0.09 *$ \\
\hline & 75 & & 19 & & 60 & & & \\
\hline
\end{tabular}



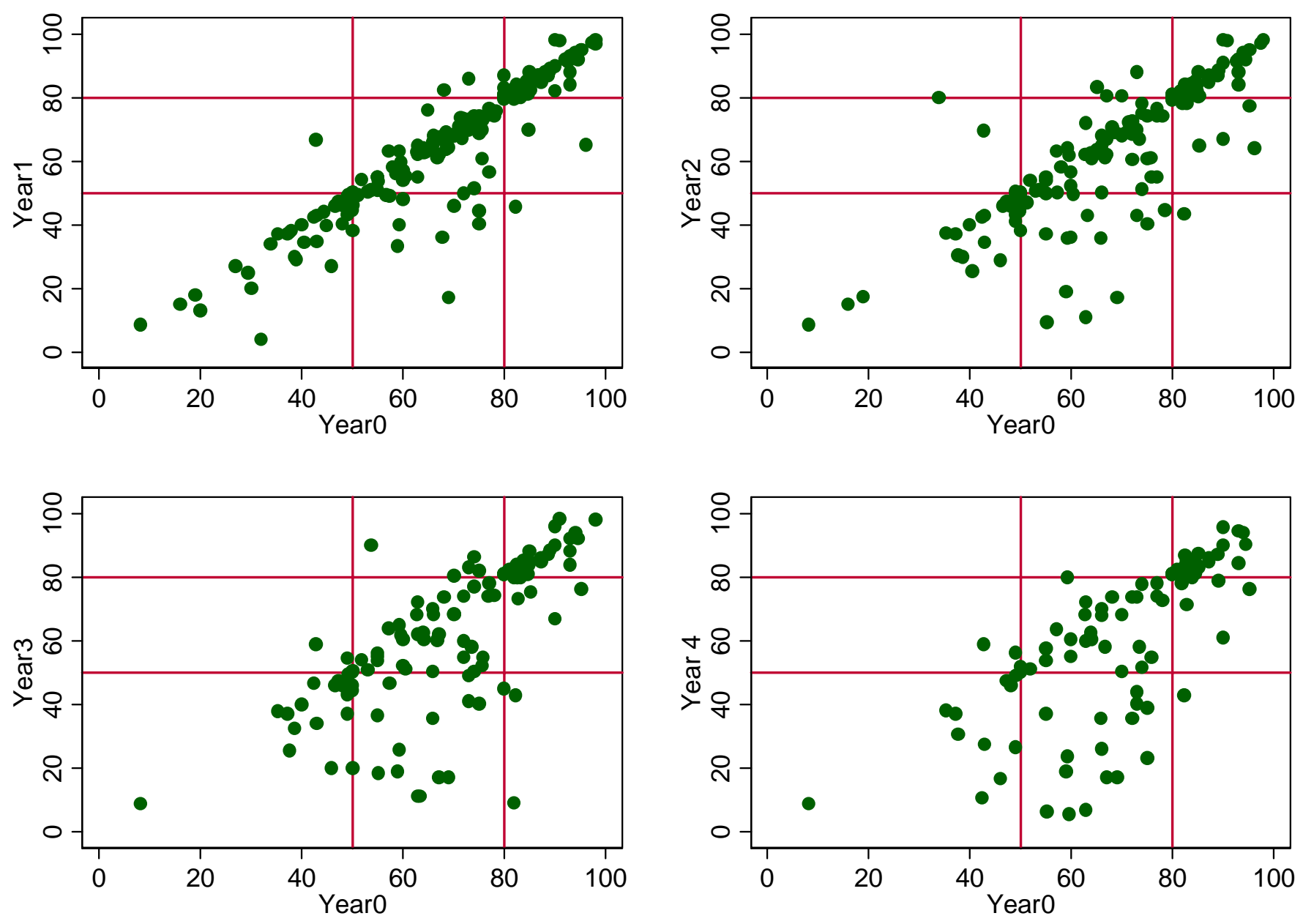

Figure 1. Scatter Plots of Ownership of Parent in Carve-out Subsidiaries from the IPO Year and Year 1, 2, 3, and 4 After IPO

The graphs exclude divested and reacquired subsidiaries. On the X-axis are ownership levels at the IPO. On the Y-axis are ownership level at one, two, three, and four years after the IPO. The ownership levels are hand-collected from the subsidiary proxy statements. 


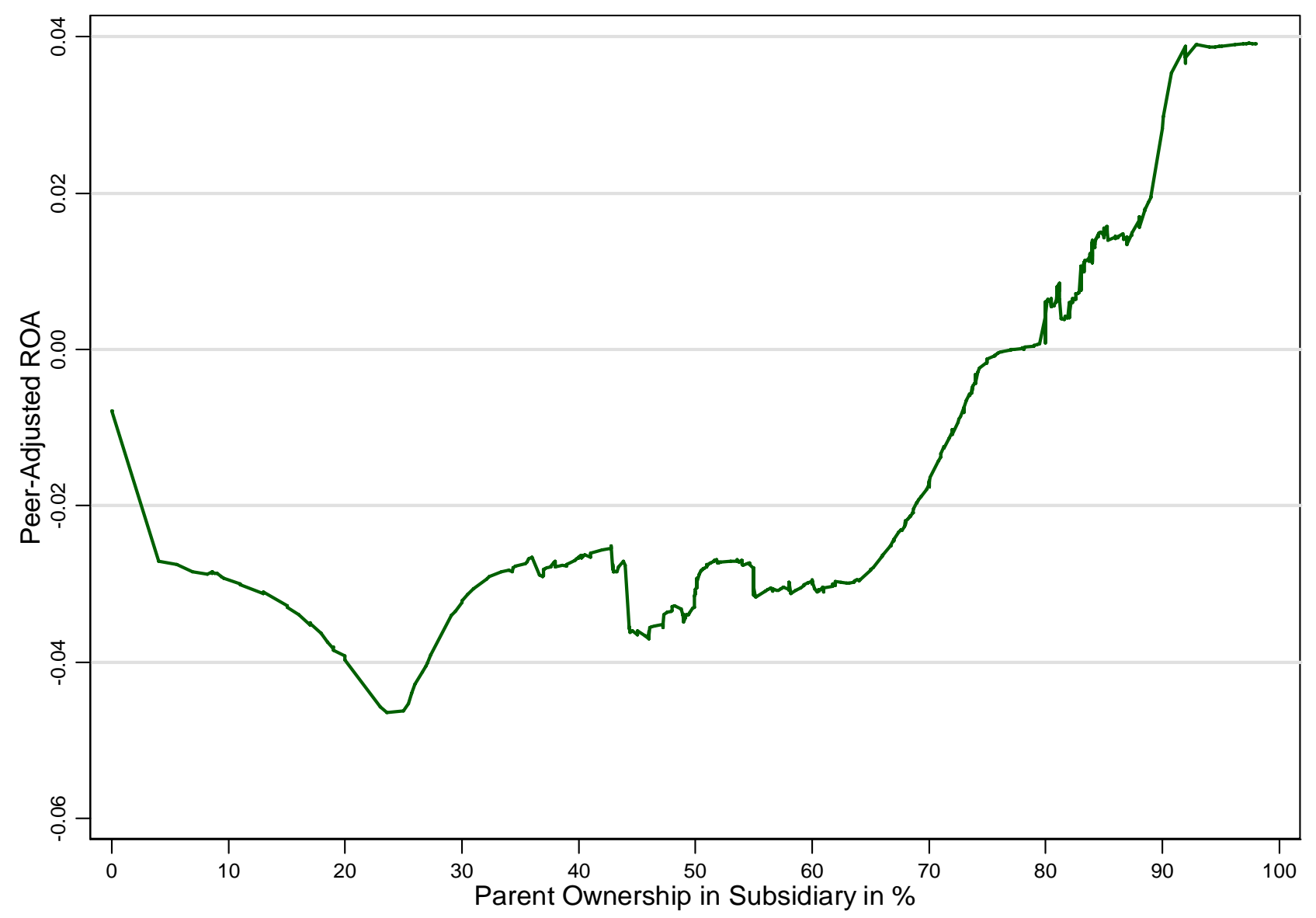

Figure 2. Locally Smoothed Subsidiary Peer-Adjusted Operating ROA

The graph is based on pooled observations for Years 1 to 4 for all carve-out subsidiaries. On the X-axis is the parent ownership level in the subsidiary. The ownership levels are hand-collected from the subsidiary proxy statements. On the Y-axis is the locally smoothed peer-adjusted operating ROA for the subsidiary. We calculate operating ROA as the ratio of Operating Cash Flow (Compustat Data Item 13) divided by Total Assets (Compustat Data Item 6).The smoothing is done using the Cleveland (1979) approach implemented in Stata 10 lowess procedure with a bandwidth parameter equal to 0.3. 


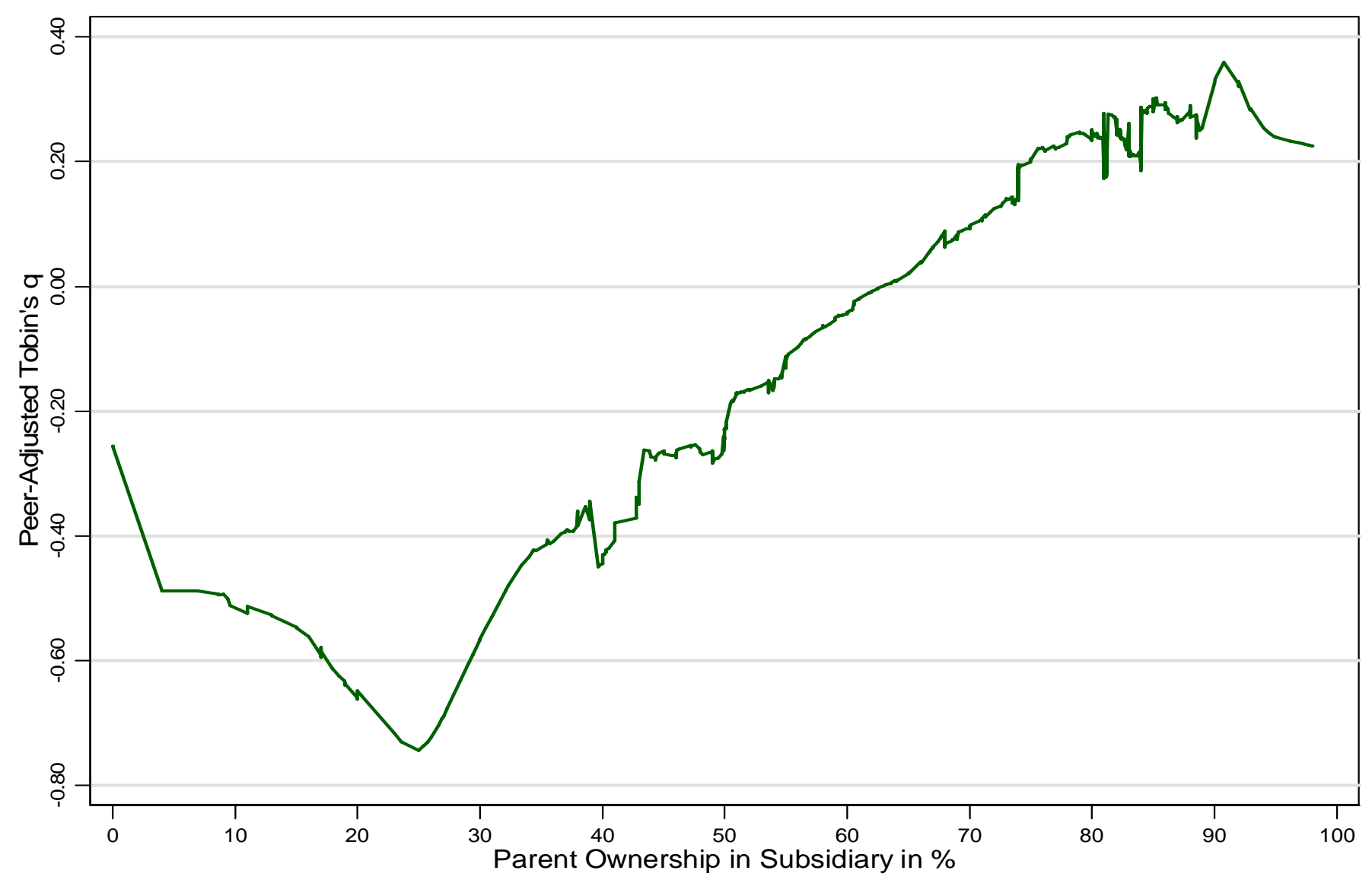

Figure 3. Locally Smoothed Subsidiary Peer-Adjusted Tobin's q Ratio

The graph is based on pooled observations for Years 1 to 4 for all carve-out subsidiaries. On the X-axis is the parent ownership level in the subsidiary. The ownership levels are hand-collected from the subsidiary proxy statements. On the Y-axis is the locally smoothed peer-adjusted Tobin's q for the subsidiary. We measure Tobin's q as (Book Value of Assets - Book Value of Equity + Market Value of Equity )/Book Value of Assets. This ratio is peer-adjusted using firms in the same Fama-French 48 industry portfolio and the closest operating ROA in Year 0. The smoothing is done using the Cleveland (1979) approach as implemented in Stata 10 lowess procedure with a bandwidth parameter equal to 0.3. 